Aktaş, E. ve Bayram, B. (2021). Anlatma becerileri kapsamında 1-8. sınıf Türkçe ders kitaplarına bir bakış: Konuşma ve yazma stratejilerinin kullanımı. Ana Dili Eğitimi Dergisi, 9(1), 1-18.

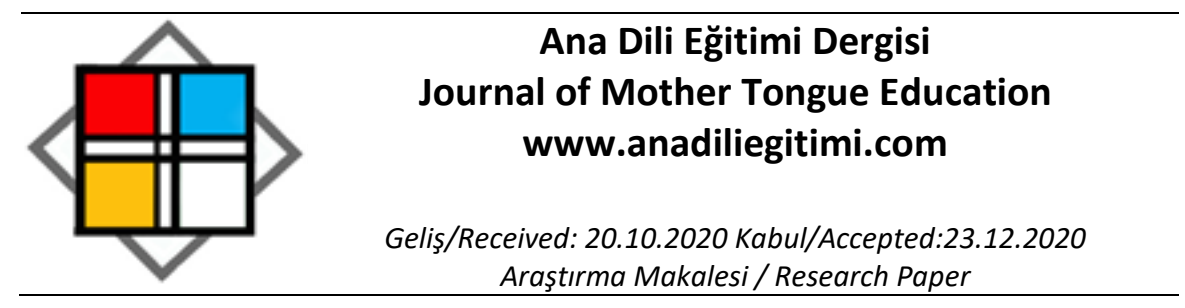

\title{
Anlatma Becerileri Kapsamında 1-8. Sınıf Türkçe Ders Kitaplarına Bir Bakış: Konuşma ve Yazma Stratejilerinin Kullanımı
}

\author{
Elif AKTAŞ \\ Bora BAYRAM ${ }^{* *}$
}

Öz

Tematik yaklaşım esas alınarak hazırlanan 2019 Türkçe Dersi Öğretim Programı́nda (TDÖP) beceri temelli bir anlayış hâkimdir. Bu yönden programda, belirlenen amaç ve kazanımlara ulaşmak için öğrenme-öğretme sürecinde birtakım etkinlikler uygulanması önerilmiştir. Türkçe derslerinde öğrencilerin anlama ve anlatma becerilerini kazanması, etkinlik temelli uygulamalarla mümkündür. Anlatma becerileri kapsamında değerlendirilen konuşma ve yazmanın geliştirilmesi için öğrenme-öğretme sürecinde birtakım stratejilerin etkin şekilde kullanılması gerekmektedir. Bu çalışmada 2019 TDÖP'ye göre hazırlanan Türkçe ders kitaplarında yer alan konuşma ve yazma stratejilerinin sınıf düzeyi ve yayınevlerine göre dağıımını tespit etmek amaçlanmıştır. Nitel araştırma yöntemiyle desenlenen çalışmada doküman inceleme yöntemi kullanılmıştır. Araştırmada 2019-2020 eğitim-öğretim yılında okutulan on dört adet 1-8. sınıf Türkçe ders kitabı incelenmiştir. Veriler, betimsel analiz tekniklerinden frekans ve yüzde analizi ile çözümlenmiştir. Araştırmanın sonuçlarına göre TDÖP'de yer alan konuşma ve yazma stratejilerine ders kitaplarında yeterli ölçüde yer verilmediği ve stratejilerin ders kitaplarında kullanımının dengeli olmadığı tespit edilmiştir.

Anahtar Kelimeler: Anlatma becerileri, konuşma stratejileri, yazma stratejileri, Türkçe Öğretim Programı.

\section{A Glance at Grades 1-8 Turkish Language Course Books in terms of Narrative Skills: Usage of Speaking and Writing Strategy Activities}

\begin{abstract}
A skill-based approach prevails in the 2019 Turkish Course Curriculum (TLC) which was prepared on the basis of a thematic approach. To that end, a recommendation was made to implement activities in the teaching-learning process to achieve the pre-determined goals and outcomes in the curriculum. Students' acquiring comprehension and narrative skills is possible through activity-based exercises in Turkish language classes. In order to improve students' speaking and writing skills which are considered to be a part of narrative skills, it is necessary to use certain strategies effectively in the teaching-learning process. The purpose of this study is to determine the distribution of speaking and writing strategy activities in the Turkish language course books prepared according to the 2019 Turkish Language Curriculum in terms of grade levels and publishers. The document analysis method was used in this study which is qualitative by design. In the study, fourteen grades 1-8 Turkish language course books that were used in the 2019-2020 academic year were examined. The data were analyzed using the descriptive frequency and percentage analysis techniques. The results showed that speaking and writing strategy activities
\end{abstract}

\footnotetext{
* Doç. Dr., Alanya Alaaddin Keykubat Üniversitesi, Eğitim Fakültesi, Türkçe Eğitimi Ana Bilim Dalı, elif.aktas@alanya.edu.tr, ORCID: 0000-0001-5573-2274

** Dr. Öğr. Üyesi, Alanya Alaaddin Keykubat Üniversitesi, Eğitim Fakültesi, Türkçe Eğitimi Ana Bilim Dalı, bora.bayram@alanya.edu.tr, ORCID: 0000-0002-0693-4651
} 
in the TLC were not sufficiently included in the textbooks and that the use of strategies was not balanced in the textbooks either.

Keywords: Narrative skills, speaking strategies, writing strategies, Turkish Language Curriculum.

\section{Giriş}

Türkçe öğretiminin temel amacı, ilköğretimden itibaren öğrencilerin anlama ve anlatma becerilerini geliştirmektir. Erken yaşlardan itibaren anlama ve anlatma becerileri gelişen birey; ana dilini doğru, etkili ve güzel kullanabilir. Ana dili eğitiminin en önemli iki boyutundan biri olan anlama becerisi, dinleme ve okumayı; anlatma becerisi ise konuşma ve yazmayı kapsamaktadır (Kavcar, Oğuzkan ve Sever, 1999). 2019 Türkçe Dersi Öğretim Programı (TDÖP), öğrencilerin hayat boyu kullanabilecekleri dinleme/izleme, konuşma, okuma ve yazma ile ilgili dil becerilerini ve zihinsel becerileri elde etmelerini sağlayacak bilgi, beceri ve değerleri içermektedir (MEB, 2019: 25). Ana dili öğretimindeki asıl amaç; kendini sözlü ve yazılı olarak ifade edebilen; okuduklarını ve dinlediklerini doğru bir şekilde anlayabilen bireyler yetiştirmektir (Büyükikiz ve Hasırcl, 2013: 58).

İnsanın duygu ve düşüncelerini anlatmak için başvurduğu önemli araçlardan biri olan yazma, konuşmadan farklı olarak sistemli bir şekilde öncelikle okullarda öğretilen bir beceri alanıdır. Genel anlamda duygu ve düşüncelerin ifade aracı olarak kabul edilen yazma; zihindekilerin yazılı olarak anlamlı bir şekilde iletilme sürecini kapsamaktadır. Yazma, düşünceleri aktarmak için gerekli sembol ve işaretleri kurallara uygun kullanma ve anlamlı olarak düşünce üretebilmedir (Akyol, 2006: 146). Yazma, üst düzey bir düşünme aracıdır ve düşünme üzerinde düşünmeyi sağlar (Güneş, 2007: 161). Bunun için öğrencilerin dinledikleri ile okuduklarını iyi anlayarak zihinlerinde yapılandırmaları gerekmektedir. Ancak ön bilgileri gözden geçirme, düzenleme ve aktarma olmak üzere üç aşamayı içeren yazma süreci oldukça karmaşık ve zordur. Yazmaya zihinde yapılandırılmış duygu, düşünce ve bilgilerin gözden geçirilmesiyle başlanmaktadır. Bu aşamada yazının amacı, yöntemi, konusu ve sınırları belirlenmektedir. Seçilen bilgiler çeşitli zihinsel işlemlerden geçirilerek düzenlenmektedir. Düzenleme sonucunda duygu ve düşünceler, cümleler aracılığıyla aktarılmaktadır. Bu üç süreç içerisinde özellikle yazma amacına ve yazılacak metin türüne uygun bir yöntem belirlemek oldukça önemlidir (MEB, 2009: 17).

Etkili ve güzel yazı yazabilmek, iyi bir yazma eğitimine bağlıdır. Özellikle bir eylem olarak yazmanın alışkanlığa dönüşebilmesinde erken yaşlarda verilen eğitimin önemi büyüktür. Bu açıdan, erken yaşlardan başlayarak öğrencilerin yazılı anlatım becerisini geliştirmeye yönelik çalışmalar yapılması gereklidir (Arıcı ve Ungan, 2008: 318). Bilişsel süreçlere dayalı olarak üretilen yazma, belleği kalıcı hâle getirerek nesiller arası iletişimi de güçlendirmektedir. Bu bakımdan tarihsel ve kültürel mirasın gelecek nesillere aktarımı açısından yazma eğitimine önem vermek gereklidir (Karagöz ve Şeref, 2020: 68).

Duygu ve düşünceleri açık ve anlaşılır olarak yazma, çeşitli zihinsel becerileri geliştirmeyi gerektirir. Öğrenciler bu yolla düşüncelerini sıralama, sınıflama, sınırlama, düzenleme ve yazma kurallarını uygulamayı öğrenirler. Bununla birlikte öğrencilerin yazma becerilerini geliştirmek için onlara bu konuda uygulamalı fırsatlar verilmeli, yazma eğitimi esnasında çeşitli stratejileri işe koşarak onların motive olması sağlanmalıdır. Yazma becerisinin alışkanlığa dönüşmesinde ise öğretmenler, çocuklar için anlamlı yazma ortamları oluşturarak öncü olmalıdır (Aktaş ve Gündüz, 2008: 216).

Yazmanın bir eylem olarak alışkanlığa dönüşmesi için geleneksel yazma yöntemleri yerine çağdaş ve yaratıcı teknikler/yöntemler/stratejiler kullanmak gereklidir. Çünkü geleneksel yazma eğitimi çalışmalarında ürün odaklı bir değerlendirme ön plandadır. Okullarda yıllarca uygulanan ürün odaklı geleneksel yazma yaklaşımında öğretmenler, öğrencilerin yazma sürecini ve bu süreçteki gelişimini değil; metnin son hâlini değerlendirmeye odaklanırlar. Bu sebeple öğrenciler, yazma sürecindeki hatalarının farkına varmadıkları için bilinçli bir şekilde yazmayı öğrenememektedirler. Kalıcı ve yanlış öğrenmelere de neden olan bu durum, öğrencinin yazmaya karşı olumsuz tutum geliştirmesine de neden olmaktadır (Karatay ve Aksu, 2017: 315). Okullarda kompozisyon, yazılı anlatım ve yazma kavramlarıyla belirtilen uygulama, öğrencinin genellikle önceden belirlenmiş bir konu ile ilgili duygu ve düşünceleri bazı kurallar çerçevesinde tam ve eksiksiz olarak anlatabilmesi şeklinde yürütülmektedir. Bu şekilde yürütülen yazma çalışmaları, öğrencilerin yazma becerilerini 
geliştirmeyeceği gibi yazmaya karşı olumsuz tutum edinmelerine de neden olmaktadır. Bu nedenle yazma eğitiminde farklı tür ve içerikte yazma çalışmalarının yaptırılması ve yaratıcı yazma yaklaşımının uygulanması gerekmektedir (Göçer, 2010: 179; Yangın, 2002'den akt. Göçer, 2010: 179; Küçük, 2006: 182). Yazma çalışmalarının geleneksellikten kurtulması için süreç odaklı bir anlayış gözetilmeli, ortaya çıkan üründen ziyade öğrencinin yazma becerisinin gelişimi izlenmeli ve yaratııı/çağdaş teknikler kullanılmalıdır. Bununla birlikte yazma süreci öncesinde yazma stratejisinin belirlenmesi, öğrencinin yazmaya yönelik motivasyonunu artırmada, dikkat çekmede ve yazma alışkanlığı edindirmede önemli hususlardan biridir.

Anlatma becerilerinin bir diğer bileşeni olan konuşma; bireyin duygu ve düşüncelerini söz ile karşı tarafa aktarmasıdır. Duygu ve düşüncelerin seslerden oluşan semboller aracilığıyla sözel olarak aktarılması (Demirel, 2003: 88) demek olan konuşma becerisi, kişinin kendini ifade etmesi kadar sosyalleşmesi ile de yakından ilgili olduğu için psikoloji, sosyal psikoloji, davranış ve iletişim bilimleri gibi bilim dallarının alanına da girmektedir (Yalçın, 2002: 97). Bireysel boyutundan ziyade toplumsal yönüyle ön plana çıkan konuşma; okul, iş ve toplum yaşamında başarıyı belirleyen etmenlerden biridir (Sever, 2004: 22). Insanlar arasındaki etkileşimi, duygu ve bilgi alışverişini sağlayan konuşma, bireyin toplum içinde yaşamasının bir sonucu olarak ortaya çıkmıştır. Bu nedenle konuşma bütün öğrenme alanları ile doğrudan ilişkili olup bireyin kendisini ifade edebilmesi açısından önemli bir beceri alanıdır (Akyol, 2006: 20). Bireyler ve birey-toplum arasında gerçekleşen sözlü iletişim ne kadar etkili, düzenli ve açık olursa aynı oranda başarı sağlanır (Kurudayıoğlu, 2003: 288).

Bir anlaşma ve sosyalleşme aracı olan konuşma; günümüzde göze ve kulağa hitap eden alternatif pek çok anlaşma aracı bulunduğu hâlde düşüncelerin ve duyguların ifadesi noktasında insanlığın var oluş tarihinden beri önemini korumaktadır (Başaran ve Erdem, 2009: 744). Konuşma, Türkçenin temel dil becerilerinden biri olup dinleme ile birlikte edinilmektedir. Nitekim çocuklar, dil edinme sürecine dinleme ile başlamaktadırlar. Sonra dinledikleri sesleri taklit ederek konuşmaya başlamaktadırlar. Önceleri sistemsiz olarak çevresel faktörlerin etkisiyle taklit ile başlayan konuşma, okulda sistematik bir şekilde öğretilmektedir. Dinleme gibi konuşma da diğer öğrenme alanlarına temel oluşturmaktadır. Nitekim insan sosyal bir varlıktır ve tek başına yaşayamaz. Çocuklar kendilerini ifade etmek, öğrenmek, zihinsel yapılarını geliştirmek ve sosyalleşmek için konuşma becerilerini kullanırlar. Konuşarak kendini ifade eden öğrenciler, bu becerilerini bir öğrenme aracı olarak hayat boyu kullanırlar. Bu nedenle belli bir düzeyde konuşma becerisi edinmiş olarak okula başlayan çocukların konuşma becerilerinin sistemli birtakım faaliyetlerle geliştirilmesi gerekmektedir. Konuşma becerisini geliştirmek için yapılacak çalışmalardan biri de amaca uygun yöntem belirlemedir. Konuşma öncesi yöntem/strateji belirlemek; motivasyonu sağlamada ve duygu-düşünceleri düzenlemede oldukça önemlidir. Bu nedenle öğrencilerin duygu ve düşüncelerini aktarmalarını sağlamak için strateji belirleme çalışması mutlaka yapılmalıdır.

Konuşma süreci; ön bilgileri gözden geçirme, düzenleme ve aktarma olmak üzere üç aşamayı içermektedir. Konuşmaya öncelikle duygu, düşünce ve bilgilerin zihinde yapılandırılıp gözden geçirilmesiyle başlanmaktadır. Sonraki aşamada konuşmanın amacı, yöntemi, konusu ve sınırları belirlenmektedir. Ardından belirlenen amaç ve yöntemlere göre aktarılacak duygu, düşünce ve bilgiler seçilmektedir. En son aşamada ise duygu, düşünce ve bilgilerin birtakım zihinsel işlemlerden geçirilerek düzenlenmesi yer almaktadır (MEB, 2009). Konuşma becerilerini geliştirmek için bu üç aşamada yapılacak çalışmalara ağırlık verilmelidir.

Bireysel ve toplumsal açıdan önemli olan konuşma, doğuştan getirilen bir yetenek değil; sonradan kazanılan ve geliştirilen bir beceridir (Temizkan, 2009: 93). Oysa özelikle dinleme ve konuşma, okul öncesi dönemde edinildiği düşünüldüğünden okullarda yeterince üzerinde durulmayan iki beceri alanıdır (Doğan, 2009; Yalçın, 2002; Doğan, 2013). Bu nedenle konuşma ve yazma becerisinin geliştirilmesi için spontane ve geleneksel bir yaklaşım yerine sistemli bir öğretim faaliyeti yürütülmelidir. Bu sayede, bireyin yaşam boyu kullanacağı anlatma becerileri gelişebilir. Aksi takdirde tüm yaşamı boyunca kendini yazılı ve sözlü olarak ifade edemeyen bireyler ortaya çıkmaktadır. 
Türkçe dersi tüm derslerin temelinde yer alan mihver bir derstir. Çünkü anlama ve anlatma becerileri gelişmeyen bir öğrencinin diğer derslerde de başarılı olması beklenemez. Zira Türkçe öğretiminin temel amacı, bireylerin anlama ve anlatma becerilerini geliştirmektir. 2019 yılında güncellenen öğretim programlarında öğrencilerin hem ulusal hem de uluslararası düzeyde; kişisel, sosyal, akademik ve iş hayatlarında ihtiyaç duyacakları becerileri içeren sekiz temel yetkinliğe yer verilmiştir. Bu yetkinliklerin ilki de ana dilde iletişim olarak belirtilmiştir (MEB, 2019: 4).

Türkçe öğretiminde belirlenen amaç ve kazanımlara ulaşmak, etkinlik temelli uygulamalarla mümkündür. Beceri temelli bir anlayışla hazırlanan TDÖP'de de öğrencilerin aktif bir şekilde öğrenme sürecine katılmaları gerektiği vurgulanmaktadır. Anlama ve anlatma becerilerin geliştirilmesi için birtakım stratejilerin etkin olarak kullanılması gerekmektedir. TDÖP'de, her sınıf düzeyinde konuşma ve yazma becerileri ile ilgili kazanımlara yer verilmiştir. Bu kazanımlardan özellikle her sınıf seviyesinde tekrar eden "Yazma stratejilerini uygular." ile "Konuşma stratejilerini uygular." şeklindeki ifadeler, strateji kavramının ne anlama geldiği ve nasıl algılandığı sorununu da beraberinde getirmiştir. Nitekim yapılan araştırmalar, öğretmenlerin öğrenme-öğretme sürecinde uygulamak zorunda oldukları bu stratejilerle ilgili farkındalıklarının düşük olduğunu ortaya koymuştur (Esendemir, 2019). Bu stratejilerin 2019 TDÖP'deki dağılımı Tablo 1 ve Tablo 2'de gösterilmiştir:

Tablo 1.

Türkçe Öğretim Programındaki Konuşma Stratejileri

\begin{tabular}{|c|c|c|c|c|c|c|c|c|}
\hline Konuşma Stratejileri & $\begin{array}{l}1 . \\
\text { Sinıf }\end{array}$ & $\begin{array}{l}2 . \\
\text { SInIf }\end{array}$ & $\begin{array}{l}3 . \\
\text { sinif }\end{array}$ & $\begin{array}{l}4 . \\
\sin I f\end{array}$ & $\begin{array}{l}5 . \\
\text { Sinıf }\end{array}$ & $\begin{array}{l}6 . \\
\text { sinif }\end{array}$ & $\begin{array}{l}7 . \\
\text { sinif }\end{array}$ & $\begin{array}{l}8 . \\
\sin I f\end{array}$ \\
\hline İkna edici konuşma & - & - & - & - & - & - & - & $\sqrt{ }$ \\
\hline Eleştirel konuşma & - & - & - & - & - & - & $\sqrt{ }$ & $\sqrt{ }$ \\
\hline Katılımlı konuşma & - & - & - & - & - & - & $\sqrt{ }$ & - \\
\hline Empati kurarak konuşma & - & - & - & - & - & - & $\sqrt{ }$ & $\sqrt{ }$ \\
\hline Güdümlü konuşma & - & - & - & - & $\sqrt{ }$ & $\sqrt{ }$ & $\sqrt{ }$ & $\sqrt{ }$ \\
\hline $\begin{array}{ll}\text { Kelime/kavram } & \text { havuzundan } \\
\text { seçerek konuşma } & \end{array}$ & - & - & - & - & $\sqrt{ }$ & $\sqrt{ }$ & - & - \\
\hline Tartışma & - & - & - & - & - & - & $\sqrt{ }$ & $\sqrt{ }$ \\
\hline Serbest konuşma & - & - & - & - & $\sqrt{ }$ & $\sqrt{ }$ & - & - \\
\hline Yaratıcı konuşma & - & - & - & - & - & $\sqrt{ }$ & $\sqrt{ }$ & $\sqrt{ }$ \\
\hline Hafizada tutma & - & - & - & - & - & $\sqrt{ }$ & - & - \\
\hline Planlı/hazırlıklı konuşma & - & - & - & - & - & - & - & - \\
\hline Geleneksel konuşma & - & - & - & - & - & - & - & - \\
\hline
\end{tabular}

(MEB, 2009a; MEB, 2009b; MEB, 2019).

Tablo 1'de yer alan konuşma stratejileri son iki TDÖP'nin (2005 ve 2019), kazanım ve açıklamalarının gözden geçirilmesiyle belirlenmiştir. Buna göre tabloda 12 konuşma stratejisi yer almaktadır. Tablo 1'e göre TDÖP'de "Konuşma stratejilerini uygular." kazanımı altında ilkokul düzeyinde herhangi bir konuşma stratejisine yer verilmemiştir. Çünkü konuşma stratejileri ilkokulda nezaket kuralları ve dikkatini yoğunlaştırma kapsamında değerlendirilmiştir. 5-8. sınıflar arasında ise konuşma stratejileri açıkça belirtilmiş olmakla birlikte 'bunun gibi' ifadesi ile çeşitlendirilmeye çalışılmıştır. Bu durum, öğretmene bir serbestlik tanısa da uygulama boyutunda çoğu zaman bir belirsizliğe de neden olmaktadır. Programda bu stratejilerin özellikle kazanım ve açıklama boyutunda açıkça belirtilmesi, sınıf seviyesine göre düzenli ve dengeli dağıtılması gerekliliği ortaya çıkmaktadır.

Programda konuşma stratejilerin ilkokul düzeyinde uygulanması kapsamında kazanım açıklaması yer almazken bazı kazanımların bu stratejilere atıfta bulunduğu dikkat çekmektedir. Örneğin "T.2.2.2. Hazırıksız konuşmalar yapar, T.2.2.3. Çerçevesi belirli bir konu hakkında konuşur, T.4.2.5. Sınıf içindeki tartışma ve konuşmalara katıır." gibi kazanımlar bu stratejilere atıfta bulunmaktadır. Bu durum esasında bir kavram karmaşasına neden olmaktadır. Öğretmenlerin konuşma stratejileri ifadesinden anladıkları, ders kitaplarında ise bu stratejilerin hangi etkinliklerle 
uygulamaya döküldüğü belirsiz bir konudur. Öğretim programının bu belirsizliğin önüne geçmesi gerekmektedir.

Ders kitaplarında bütün bu konuşma stratejilerinin yanı sıra geleneksel tarzda bir yaklaşımın ürünü olarak öğrencilerin bir özlü söz, atasözü ve deyim açıklamasını sözlü olarak yapmalarını isteyen etkinlere rastlamak mümkündür. Yazma çalışmalarında olduğu gibi öğrencilerin birtakım basmakalıp ifadelerden ne anladıklarını sözlü ya da yazılı olarak açıklamalarını istemek, klasik bir anlayışı yansıtmaktadır (Göçer, 2010). Öğrencileri zihinsel olarak hazırlamadan, onların yaratıcı düşünmelerine olanak vermeden bu şekilde yürütülen konuşma eğitiminin başarıya ulaşması mümkün değildir. Yapılan araştırmalar, öğretmenlerin de sınıf ortamında en çok bu türden yazma ve konuşma etkinlikleri uyguladığını ortaya koymaktadır (Kemiksiz, 2016). Öğrencilerin anlatım becerilerini geliştirmek için atasözü ve özdeyiş açıklatmaktan kaçınılmalı, bunun yerine öğrencinin kendi düşüncelerini serbestçe ifade edebileceği ve özgün bir metin oluşturma becerileri geliştirilmelidir. Zira klasik etkinliklerin ve stratejilerin öğrencilerin kendi birikimlerini ve yaratıcılıklarını kullanarak yeni bir metin oluşturma becerilerinin geliştirilmesinde çok sınırlı etkiye sahip olduğu gözden uzak tutulmamalıdır (Güfta ve Zorbaz, 2008).

Tablo 2.

Türkçe Ögrretim Programındaki Yazma Stratejileri

\begin{tabular}{|c|c|c|c|c|c|c|c|c|}
\hline Yazma Stratejileri & $\begin{array}{l}1 . \\
\text { sinıf }\end{array}$ & $\begin{array}{l}2 . \\
\text { sinıf }\end{array}$ & $\begin{array}{l}3 . \\
\text { sinIf }\end{array}$ & $\begin{array}{l}4 . \\
\text { sinıf }\end{array}$ & $\begin{array}{l}5 . \\
\text { sinıf }\end{array}$ & $\begin{array}{l}6 . \\
\text { sinıf }\end{array}$ & $\begin{array}{l}7 . \\
\text { sinıf }\end{array}$ & $\begin{array}{l}8 . \\
\text { sinıf }\end{array}$ \\
\hline Not alma & - & - & - & - & - & - & $\sqrt{ }$ & $\sqrt{ }$ \\
\hline Özet çıkarma & - & - & - & - & - & - & $\sqrt{ }$ & - \\
\hline Boşluk doldurma & - & - & - & - & $\sqrt{ }$ & $\sqrt{ }$ & - & - \\
\hline Kelime/ kavram havuzundan seçerek yazma & - & - & - & - & - & - & $\sqrt{ }$ & $\sqrt{ }$ \\
\hline Serbest yazma & - & - & - & - & - & $\sqrt{ }$ & $\sqrt{ }$ & $\sqrt{ }$ \\
\hline Kontrollü yazma & - & - & - & - & - & $\sqrt{ }$ & $\sqrt{ }$ & - \\
\hline Güdümlü yazma & - & - & - & - & $\sqrt{ }$ & $\sqrt{ }$ & - & - \\
\hline Yaratıcı yazma & - & - & - & - & - & - & - & $\sqrt{ }$ \\
\hline Metin tamamlama & - & - & - & - & $\sqrt{ }$ & $\sqrt{ }$ & - & - \\
\hline Tahminde bulunma & - & - & - & - & - & $\sqrt{ }$ & - & - \\
\hline Metni yeniden yazma & - & - & - & - & $\sqrt{ }$ & $\sqrt{ }$ & - & - \\
\hline Metinden hareketle yeni metin yazma & - & - & - & - & - & - & $\sqrt{ }$ & $\sqrt{ }$ \\
\hline Duyulardan hareketle yazma & - & - & - & - & - & - & - & $\sqrt{ }$ \\
\hline İş birliği yaparak (paylaşarak) yazma & & - & - & - & $\sqrt{ }$ & $\sqrt{ }$ & - & - \\
\hline Eleştirel yazma & - & - & - & - & - & - & - & - \\
\hline Betimleyici yazma & - & - & - & - & - & - & - & - \\
\hline Hikâye edici yazma & - & - & - & - & - & - & - & - \\
\hline Oluş sırası karışık cümlelerden metin yazma & - & - & - & - & - & - & - & - \\
\hline Hikâyenin ortasını yazma & - & - & - & - & - & - & - & - \\
\hline Karşılaştırmalı yazma & - & - & - & - & - & - & - & - \\
\hline Planlı yazma & - & - & - & - & - & - & - & - \\
\hline Empati kurarak yazma & - & - & - & - & - & - & - & - \\
\hline Dikte & - & - & - & - & - & - & - & - \\
\hline Görsellerden hareketle yazma & - & - & - & - & - & - & - & - \\
\hline Geleneksel yazma & - & - & - & - & - & - & - & - \\
\hline Bilgilendirici yazma & - & - & - & - & - & - & - & - \\
\hline
\end{tabular}

(MEB, 2009a; MEB, 2009b; MEB, 2019).

Tablo 2'de yer alan yazma stratejileri son iki TDÖP'nin (2005 ve 2019) kazanım ve açıklamalarının gözden geçirilmesiyle belirlenmiştir. Tabloda 25 yazma stratejisi yer almaktadır. Tablo 
2'ye göre TDÖP'de ilkokul düzeyinde tüm sınıf seviyelerinde yer alan "Yazma stratejilerini uygular." kazanımı altında hiçbir açıklama yapılmamıştır. Dolayısıyla bu kazanımın ne ifade ettiği muğlaktır. Bununla birlikte yine yazma öğrenme alanı içerisinde 1. sınıftan 8. sınıfa kadar strateji kavramına atıfta bulunan başka kazanımlar da mevcuttur. Örneğin 1. sınıf kazanımları arasında yer alan "T1.4.12.a Dikte, bakarak ve serbest yazma çalışmaları yapar." kazanımı üç yazma stratejisini barındırmaktadır. Yine benzer şekilde "T.3.4.10. Görsellerdeki olayları ilişkilendirerek yazı yazar, T.5.4.3. Hikâye edici metin yazar, T.6.4.2. Bilgilendirici metin yazar, T.5.4.15. Yazdıklarının içeriğine uygun başlık belirler." şeklindeki kazanımlar yazma stratejilerine atıfta bulunmaktadır.

Programda ayrıca 5-8. sınıflar arasında yazma stratejileri belirtilirken 'bunun gibi' ifadesi kullanılarak bir çeşitlilik sağlanmaya çalışımış ve öğretmene inisiyatif verilmiştir. Bu durum, hangi yazma stratejisinin kullanılacağı hususunda öğretmene bir esneklik sağlasa da belirsizliğe neden olmaktadır. Programda bu stratejilerin özellikle kazanım ve açıklama boyutunda açıkça belirtilmesi, sınıf seviyesine göre düzenli ve dengeli dağıtılması gerekmektedir.

Tablo 2'de yer alan stratejilerden biri de geleneksel yazmadır. Yaratıcı yazmanın karşıtı olarak düşünebileceğimiz geleneksel yazma stratejisinde; öğrencilerden bir atasözü, deyim veya özlü söz açıklaması istenmektedir (Güfta ve Zorbaz, 2008; Göçer, 2010). Bu tür bir yazma yaklaşımı, öğrencilerin yazma becerisini geliştirmediği gibi onların yazmaya karşı tutumunu da olumsuz yönde etkilemektedir. Yazma etkinliklerinde farklı yöntem ve teknikler kullanmamanın, öğrencilerin başarısını olumsuz yönde etkileyen diğer bir faktör olduğu da unutulmamalıdır (Tağa ve Ünlü, 2013).

Öğretim programlarında yer alan kazanımlar, öğrenme-öğretme sürecinde birtakım etkinlikler yoluyla öğrencilere kazandırımaktadır. Beceri ve etkinlik temelli bir anlayışla hazırlanan öğretim programında dinleme, konuşma, okuma ve yazmayı kapsayan dilsel alanlar, bütüncül bir anlayış gözetilerek etkinlik temelli uygulamalarla çocuklara öğretilmelidir. Ders kitaplarının bu süreçte en çok kullanılan öğretim materyallerinin başında geldiği düşünüldüğünde nitelik sorunu da ön plana çıkmaktadır. 2019 TDÖP esas alınarak hazırlanan Türkçe ders kitaplarındaki etkinliklerin öğrencilerin okuma, yazma, konuşma, dinleme ile dil bilgisi becerilerini geliştirecek şekilde tasarlanması gerekmektedir. Ancak bu etkinliklerin öneri niteliğinde olduğu ve öğretmenlerin istedikleri etkinlikleri kendilerinin de tasarlayabilecekleri unutulmamalıdır.

Ders kitaplarının öğrenme-öğretme sürecinde kullanılan temel materyallerden biri olduğu göz önünde bulundurulduğunda bu kitaplardaki nitelik sorununun önemli olduğu söylenebilir. Beceri ve etkinlik temelli bir anlayışla hazırlanan ders kitaplarının niteliğini tespit etmek başarıya ulaşma açısından önemlidir. İlgili literatür incelendiğinde ders kitaplarındaki anlatma stratejileri, yöntem ve tekniklerinin kullanımını inceleyen çeşitli türden çalışmalara rastlamak mümkündür.

Okur, Süğümlü ve Göçen (2013), Türkçe ders materyallerinde (ilk ve orta) ikna ediciliğe bir metin türü olarak değil; yöntem-teknik ve kazanım olarak yer verildiğini tespit etmişlerdir.

Coşkun ve Narinç (2018), 5. sınıf Türkçe ders kitabındaki etkinliklerde en çok yer alan yazma yönteminin metin tamamlama; en çok yer verilen konuşma yönteminin ise kendisini karşısındakinin yerine koyarak konuşma (empati kurma) olduğu sonucuna ulaşmışlardır.

Yılmaz ve Cımbız (2016), 3. sınıf Türkçe ders kitabındaki konuşma becerisi ile ilgili etkinlikleri inceledikleri çalışmalarında; soru sorma, günlük hayatla ilgili konuşma, yeni öğrenilen kelimelerle ilgili cümleler söyleme, resim inceleme-yorumlama ve tartışma etkinliklerinin konuşma becerisini geliştirmek için sıkça kullanılan teknikler olduğunu tespit etmişlerdir.

Benzer ve Ünsal (2019), Türkçe öğretmenlerinin konuşma eğitimi etkinlikleri kapsamında en sık kullandıkları stratejileri belirlemeye yönelik çalışmalarında, öğretmenlerin Türkçe öğretiminde en fazla tartışma ve katılımlı konuşmayı kullandıkları tespit etmişlerdir.

Şimşek ve Demirel de (2020) konuşma ve yazma stratejilerinin 7. sınıf Türkçe ders kitaplarında yeterli ve dengeli bir dağılım göstermediğini tespit etmişlerdir.

$\mathrm{Bu}$ çalışmalar incelendiğinde ders kitaplarındaki konuşma ve yazma stratejilerinin sınıf düzeylerine ve yayınevlerine göre dağıımını kapsamlı bir şekilde inceleyen çalışmaların çok kısıtlı olduğu dikkat çekmektedir. Bu çalışma, ilkokul ve ortaokul düzeyindeki tüm ders kitaplarında kullanılan konuşma ve yazma stratejilerini kapsamlı ve detaylı bir şekilde incelemeyi amaçlamaktadır. Öğrenme-öğretme sürecinde en çok kullanılan materyallerin başında gelen ders kitaplarının önemi 
yadsınamaz. İyi hazırlanmış bir ders kitabı, öğretim programındaki kazanımların gerçekleştirilebilmesi için önemli bir araçtır. Öğretim programı, uygulama boyutunda kimi zaman ders kitabı hazırlayıcılarına ve öğretmenlere esneklik tanımaktadır. Özellikle yazma ve konuşma becerisini geliştiren etkinlikler kapsamında nitelikli kitapların uygulayıcılara ilham verdiği de bilinmektedir. Öğrenme-öğretme sürecini ders kitabındaki etkinlikleri uygulayarak geçiren öğretmen açısından da iyi hazırlanmış bir ders kitabının önemi büyüktür. Bu nedenle ders kitapları her açıdan dikkatle hazırlanmalı, kullanıcılarına iyi bir rehber olmalıdır. Türkçe ders kitapları da bu anlamda konuşma ve yazma stratejilerini etkili, doğru ve işlevsel bir şekilde etkinliğe dönüştürebilmelidir.

Bu araştırmanın amacı, 2019 TDÖP esas alınarak hazırlanan 1-8. sınıf Türkçe ders kitaplarındaki konuşma ve yazma stratejilerinin sınıf düzeylerine ve yayınevlerine göre dağıımının belirlenmesidir. Bu amaç doğrultusunda araştırmada MEB ve özel yayınevleri tarafından yayımlanan on dört Türkçe ders kitabında yer alan konuşma ve yazma stratejileri tespit edilip frekans ve yüzde değerleri hesaplanarak tablo hâline getirilmiştir. Araştırma kapsamında aşağıdaki iki soruya yanıt aranmıştır:

1. Türkçe ders kitaplarındaki konuşma stratejilerinin sınıf seviyeleri bakımından yayınevlerine göre dağılımı nedir?

2. Türkçe ders kitaplarındaki yazma stratejilerinin sınıf seviyeleri bakımından yayınevlerine göre dağılımı nedir?

\section{Araştırmanın Modeli}

\section{Yöntem}

2019 TDÖP'ye göre hazırlanan Türkçe ders kitaplarındaki konuşma ve yazma stratejilerinin sınıf düzeylerine ve yayınevlerine göre dağılımını tespit etmeyi amaçlayan bu çalışma, betimleyici bir nitel araştırma özelliği göstermektedir. Bilindiği üzere nitel araştırmalar; gözlem, görüşme ve doküman analizi gibi nitel veri toplama yöntemlerinin kullanıldığı, algıların ve olayların doğal oramda gerçekçi ve bütüncül bir biçimde ortaya konmasına yönelik nitel bir sürecin izlendiği araştırmalardır (Yıldırım ve Şimşek, 2016). Çalışmada nitel araştırma yöntemlerinden araştırılması hedeflenen olgu ve olgular hakkında bilgi içeren yazılı materyallerin analizini kapsayan doküman incelemesi kullanılmıştır (Yıldırım ve Şimşek, 2016). Bu araştırmada 2019-2020 eğitim-öğretim yılında ilk ve ortaokullarda okutulan on dört adet 1- 8. sınıf Türkçe ders kitabı konuşma ve yazma stratejilerinin dağılımı açısından doküman incelemesi yöntemiyle incelenmiştir.

\section{Veri Toplama Aracı}

Araştırmada Millî Eğitim Bakanlığı ve özel yayınevlerine ait on dört adet Türkçe ders kitabı (18. Sınıflar) konuşma ve yazma stratejilerinin dağıımı açısından incelenmiştir. Dolayısıyla söz konusu Türkçe ders kitapları bu araştırmada veri toplama aracı olarak kullanılmıştır. Bununla birlikte kitaplarda hangi stratejilerin kullanıldığını tespit etmek için ilgili literatür taranarak oluşturulan konuşma ve yazma stratejileri formu kullanılmıştır. Forma son şeklinin verilmesinde Türkçe eğitimi alan uzmanlarının ( $n=3$ ) görüşlerinden faydalanılmıştır. Formda yer alan başlıklar Tablo 1 ve 2'de belirtilmiştir. Bu doğrultuda araştırma kapsamındaki ders kitaplarında yer alan konuşma ve yazma stratejileri tespit edilip sınıflandııılmıştır. İkinci sınıflara yönelik MEB yayınevi ve 8 . sınıflara yönelik özel yayınevine ait kitapların baskısı olmadığından söz konusu kitaplar incelemeye dâhil edilmemiştir. Araştırmanın inceleme nesnesi olan ders kitapları şunlardır:

Özel Yayınevleri

1. Sınıf Türkçe Ders Kitabı-Cem Web Ofset

2. sınıf Türkçe Ders Kitabı-Koza Yayınları

3. sınıf Türkçe Ders Kitabı-Sonuç Yayınları

4. Sınıf Türkçe Ders Kitabı-Koza Yayınları

5. Sınıf Ortaokul ve İmam Hatip Ortaokulu Türkçe Ders Kitabı-Anıttepe Yayınları

6. Sınıf Ortaokul ve İmam Hatip Ortaokulu Türkçe Ders Kitabı-Ekoyay

7. sınıf Ortaokul ve İmam Hatip Ortaokulu Türkçe Ders Kitabı-Özgün Yayıncılık 
MEB Yayınevi

1. Sınıf Türkçe Ders Kitabı-MEB

3. sınıf Türkçe Ders Kitabı-MEB

4. Sınıf Türkçe Ders Kitabı-MEB

5. Sınıf Ortaokul ve İmam Hatip Ortaokulu Türkçe Ders Kitabı-MEB

6. Sınıf Ortaokul ve İmam Hatip Ortaokulu Türkçe Ders Kitabı-MEB

7. Sınıf Ortaokul ve İmam Hatip Ortaokulu Türkçe Ders Kitabı-MEB

8. Sınıf Ortaokul ve İmam Hatip Ortaokulu Türkçe Ders Kitabı-MEB

\section{Verilerin Analizi}

Araştırmada veri analizi, ham verilerin okuyucunun anlayabileceği ve gerek duyduğunda kullanabileceği bir şekle dönüştürülmesi anlamına gelen betimsel analiz tekniği kullanılarak yapılmıştır. Betimleyici analiz tekniklerinden yüzde ve frekans analizi ile çözümlenen veriler, önceden oluşturulan temalara göre sınıflandırılıp yorumlanmıştır. Öncelikle Türkçe ders kitaplarında yer alan konuşma ve yazma etkinliklerine yönelik stratejiler tespit edilmiş; ardından bu stratejiler yayınevi ve sınıf düzeyine göre sınıflandırılmıştır. Son olarak da her bir stratejiye yönelik frekans ve yüzde değerleri hesaplanarak sayısal veriler tablolaştırılmıştır.

\section{Geçerlik ve Güvenirlik}

Bu araştırmada verilerin geçerliğinin sağlanması için üçgenleme tekniği kullanılmıştır. Çünkü nitel araştırmalarda toplanan verilerin geçerliğinin sağlanması için en çok bilinen ve uygulanan strateji üçgenleme tekniğidir (Merriam, 2013). Bu araştırmada üçgenleme tekniklerinden iki veya daha fazla araştırmacının birbirlerinden bağımsız olarak analiz ettiği nitel bulguların karşılaştırılması olarak tanımlanan araştırmacı üçgenlemesi kullanılmıştır. Analizcilerin üçgenlemesi, bulguları gözden geçiren çoklu analizci kullanımıdır. Yani iki veya daha fazla kişiye aynı nitel verinin bağımsız olarak analiz ettirilmesi ve bulguların karşılaştırılmasıdır (Patton, 2014). Bu kapsamda tanımlanan bulgular araştırmacı dışında bir başka araştırmacı tarafından da incelenmiştir. İki araştırmacı tarafından bağımsız olarak analiz edilerek ulaşılan sonuçlar Miles ve Huberman'ın (1994) ortaya koyduğu güvenirlik formülü aracılığıyla hesaplanmıştır. Böylelikle \%98 çıkan uyuşum değeriyle araştırmanın güvenilir olduğunu görülmüştür. Uzlaşma göstermeyen veriler ise tartışılarak tekrar gözden geçirilip ortak karara varılmıştır. Böylelikle verilerin tamamında uzlaşma sağlanmıştır.

\section{Bulgular ve Yorum}

Konuşma ve yazma stratejilerinin sınıf seviyelerine ve yayınevlerine göre dağılımına ilişkin tespit edilen bulgular Tablo 3 ve Tablo 4'te sunulmuştur.

Tablo 3.

Konuşma Stratejilerinin Sınıf Seviyeleri Bakımından Yayınevlerine Göre Dağılımı

\begin{tabular}{|c|c|c|c|c|c|c|c|c|c|c|c|c|c|c|c|c|c|c|c|}
\hline \multirow{2}{*}{$\begin{array}{l}\text { Konuşma } \\
\text { Stratejileri }\end{array}$} & \multirow{2}{*}{$\begin{array}{l}f / \\
\%\end{array}$} & \multicolumn{9}{|c|}{$\begin{array}{l}\text { MEB Yayınları } \\
\text { Sınıflar }\end{array}$} & \multicolumn{9}{|c|}{$\begin{array}{l}\text { Özel Yayınevleri } \\
\text { Sınıflar }\end{array}$} \\
\hline & & 1 & 2 & 3 & 4 & 5 & 6 & 7 & 8 & $T$ & 1 & 2 & 3 & 4 & 5 & 6 & 7 & 8 & $T$ \\
\hline \multirow{2}{*}{$\begin{array}{l}\text { İkna } \\
\text { konuşma }\end{array}$} & $f$ & - & - & - & - & - & - & - & 1 & 1 & - & - & - & - & - & - & - & - & - \\
\hline & $\%$ & - & - & - & - & - & - & - & 1 & 0,2 & - & - & - & - & - & - & - & - & - \\
\hline \multirow[t]{2}{*}{ Eleştirel konuşma } & $f$ & 2 & - & 7 & 3 & 1 & 2 & 4 & 1 & 20 & - & 5 & 2 & 1 & - & - & 2 & - & 10 \\
\hline & $\%$ & 6 & & 10 & 4 & 1 & 2 & 5 & 1 & 4 & & 7 & 7 & 2 & & & 3 & & 3 \\
\hline \multirow[t]{2}{*}{ Katılımlı konuşma } & $f$ & - & - & - & - & 1 & - & 1 & - & 2 & - & - & 1 & - & - & - & - & - & 1 \\
\hline & $\%$ & - & - & - & - & 1 & - & 1 & - & 0,4 & - & - & 3 & - & - & - & - & - & 0,2 \\
\hline \multirow{2}{*}{$\begin{array}{l}\text { Empati kurarak } \\
\text { konuşma }\end{array}$} & $f$ & 1 & - & 4 & 4 & 8 & 3 & 6 & 5 & 31 & - & - & 1 & 3 & 5 & 3 & 6 & - & 18 \\
\hline & $\%$ & 3 & - & 6 & 6 & 11 & 3 & 7 & 7 & 6 & - & - & 3 & 8 & 8 & 4 & 10 & - & 5 \\
\hline \multirow{2}{*}{$\begin{array}{l}\text { Güdümlü } \\
\text { konuşma }\end{array}$} & $f$ & 2 & - & - & - & - & - & - & - & 2 & - & - & - & 2 & - & - & 1 & - & 3 \\
\hline & $\%$ & 6 & - & - & - & - & - & - & - & 0,4 & - & - & - & 5 & - & - & 2 & - & 1 \\
\hline Kelime/ kavram & $f$ & - & - & 1 & - & 2 & 5 & - & - & 8 & - & 3 & - & 1 & 3 & 3 & 2 & - & 12 \\
\hline
\end{tabular}


Anlatma Becerileri Kapsamında 1-8. Sınıf Türkçe Ders Kitaplarına Bir Bakış: Konuşma ve Yazma Stratejilerinin Kullanımı

\begin{tabular}{|c|c|c|c|c|c|c|c|c|c|c|c|c|c|c|c|c|c|c|c|}
\hline $\begin{array}{l}\text { havuzundan } \\
\text { seçerek konuşma }\end{array}$ & $\%$ & - & - & 1 & - & 3 & 5 & - & - & 2 & - & 4 & - & 2 & 5 & 4 & 3 & 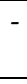 & 3 \\
\hline \multirow[t]{2}{*}{ Tartışma } & $f$ & - & - & 12 & 14 & 4 & 2 & 7 & 7 & 46 & - & - & - & 1 & 8 & 6 & 7 & - & 22 \\
\hline & $\%$ & - & - & 18 & 21 & 5 & 2 & 8 & 9 & 9 & - & - & - & 2 & 12 & 8 & 11 & - & 6 \\
\hline \multirow[t]{2}{*}{ Serbest konuşma } & $f$ & 17 & - & 40 & 36 & 29 & 30 & 23 & 33 & 208 & 10 & 37 & 18 & 20 & 23 & 31 & 21 & - & 160 \\
\hline & $\%$ & 53 & - & 60 & 53 & 39 & 32 & 28 & 43 & 42 & 91 & 54 & 60 & 50 & 35 & 38 & 33 & - & 45 \\
\hline \multirow[t]{2}{*}{ Yaratıcı konuşma } & $f$ & 10 & - & 2 & 4 & 12 & 17 & 12 & 9 & 66 & 1 & 20 & 2 & 7 & 15 & 17 & 10 & - & 72 \\
\hline & $\%$ & 31 & - & 3 & 6 & 16 & 18 & 14 & 12 & 13 & 9 & 29 & 7 & 18 & 23 & 21 & 16 & - & 20 \\
\hline \multirow[t]{2}{*}{ Hafızada tutma } & $f$ & - & - & - & - & - & 1 & - & - & 1 & - & - & - & - & - & 2 & - & - & 2 \\
\hline & $\%$ & - & - & - & - & - & 1 & - & - & 0,2 & - & - & - & - & - & 2 & - & - & 0,5 \\
\hline \multirow{2}{*}{$\begin{array}{l}\text { Geleneksel } \\
\text { konuşma }\end{array}$} & $f$ & - & - & 1 & - & 2 & 2 & 4 & 5 & 14 & - & 1 & - & - & 1 & 1 & 2 & - & 5 \\
\hline & $\%$ & - & - & 1 & - & 3 & 2 & 5 & 7 & 3 & - & 1 & - & - & 2 & 1 & 3 & - & 1 \\
\hline \multirow{2}{*}{$\begin{array}{l}\text { Planlı/hazırlıklı } \\
\text { konuşma }\end{array}$} & $f$ & - & - & - & 7 & 16 & 31 & 26 & 15 & 95 & - & 3 & 6 & 5 & 10 & 18 & 12 & - & 54 \\
\hline & $\%$ & - & - & - & 10 & 21 & 33 & 31 & 20 & 19 & - & 4 & 20 & 13 & 15 & 22 & 19 & - & 15 \\
\hline \multirow{2}{*}{ Toplam } & $f$ & 32 & - & 67 & 68 & 75 & 93 & 83 & 76 & 494 & 11 & 69 & 30 & 40 & 65 & 81 & 63 & - & 359 \\
\hline & $\%$ & 6 & - & 14 & 14 & 15 & 19 & 17 & 15 & 100 & 3 & 19 & 8 & 11 & 18 & 23 & 18 & - & 100 \\
\hline
\end{tabular}

Tablo 3'te 2019-2020 eğitim-öğretim yılında 1-8. sınıflarda okutulmakta olan MEB ve özel yayınevlerine ait Türkçe ders kitaplarında konuşma stratejilerinin bulunma durumuna ilişkin veriler yer almaktadır. Buna göre MEB tarafından basılmış Türkçe ders kitaplarında 494, özel yayınevleri tarafından basılmış Türkçe ders kitaplarında 359 konuşma stratejisi tespit edilmiştir. MEB kitaplarında en fazla konuşma stratejisine yer veren ders kitabı 6. sınıf ders kitabıdır $(f=93)$. Bunu 7. $\sin ı f(f=83), 8$. $\operatorname{sın} \mathfrak{f}(f=76)$ ve 5 . sınıf $(f=75)$ ders kitapları takip etmektedir. Özel yayınevlerine ait kitaplar içinde konuşma stratejisine en fazla yer veren ders kitabı ise 6 . sınıf ders kitabıdır ( $f=81$ ). Bunu sırasıyla 2. sınıf $(f=69)$ ve 5 . sınıf ders kitapları $(f=65)$ izlemektedir. Her iki yayınevine ait ders kitaplarında konuşma stratejilerinin sınıf seviyeleri bakımından sistematik bir artış veya azalma göstermediği görülmektedir.

MEB'e ait ders kitapları içinde en fazla kullanılan konuşma stratejisi serbest konuşmadır (\%42). Bunu sırasıyla planlı/hazırlıklı konuşma (\%19), yaratıcı konuşma (\%13), tartışma (\%9), empati kurarak konuşma (\%6) izlemektedir. Özel yayınevlerine ait Türkçe ders kitapları içinde en çok kullanılan konuşma stratejisi ise serbest konuşmadır (\%45). Ardından yaratıcı konuşma (\%20), planlı/hazırlıklı konuşma (\%15), tartışma (\%6), empati kurarak konuşma (\%5) gelmektedir. Hem MEB hem de özel yayınevlerine ait ders kitaplarında en çok kullanılan konuşma stratejilerinin sırası benzerlik göstermektedir. Buna göre her iki yayınevi grubunda da en çok kullanılan konuşma stratejisi serbest konuşma olmuştur. Bunun sebebi, serbest konuşma etkinliklerinin öğrencilerin duygu ve düşüncelerini daha rahatça ifade edebilmelerini sağlayan bir ortam oluşturmasıdır. Özellikle temel eğitimin ilk kademesinde serbest konuşma etkinliklerine daha fazla yer verilmelidir. Bu sayede öğrenciler, kendilerini rahatça ifade etme becerisi kazanabilirler. Daha ilk yıllardan itibaren yapılan kurallı ve planlı etkinlikler, öğrenciyi sıkabilir.

MEB'e ait Türkçe ders kitaplarında sınıf seviyeleri açısından en sık başvurulan konuşma stratejilerine bakıldığında, serbest konuşma stratejisinin en çok 3. sınıf (\%60), 1. sınıf (\%53), 4. sınıf (\%53) ve 8. sınıf (\%43); planlı/hazırlıklı konuşma stratejisinin en çok 6. sınıf (\%33), 7. sınıf (\%31), 5. sınıf (\%21) ve 8. sınıf (\%20); yaratıcı konuşma stratejisinin en çok 1. sınıf (\%31), 6. sınıf (\%18), 5. sınıf (\%16) ve 7. sınıf (\%14); tartışma stratejisinin en çok 4. sınıf (\%21) ve 3. sınıf (\%18); empati kurarak konuşma stratejisinin en çok 5. sınıf (\%11), 7. sınıf (\%7) ve 8. sınıf (\%7) ders kitaplarında kullanıldığı görülmektedir. Özel yayınevlerinin hazırladığı Türkçe ders kitaplarında başvurulan konuşma stratejilerine sınıf düzeyinde bakıldığında serbest konuşma stratejisinin en çok 1. sınıf (\%91), 3. sınıf (\%60), 2. sınıf (\%54) ve 4. sınıfta (\%50); yaratıcı konuşma stratejisinin en çok 2. sınıf (\%29), 5. sınıf (\%23), 6. sınıf (\%21) ve 4. sınıfta (\%18); planlı/hazırlıklı konuşma stratejisinin en çok 6. sınıf (\%22), 3. sınıf (\%20) ve 7. sınıfta (\%19); tartışma stratejisinin en çok 5. sınıf (\%12) ve 7. sınıfta (\%11); empati kurarak konuşma stratejisinin en çok 7. sınıf (\%10), 5. sınıf (\%8) ve 4. sınıfta (\%8) kullanıldığı belirlenmiştir. 
Tablo 3'e göre MEB'e ait Türkçe ders kitaplarında bir konuşma stratejisi olarak hafızada tutma stratejisine çok az yer verilmiştir. Bunun yanında ikna edici konuşma sadece 8 . sınıf, güdümlü konuşmaysa sadece 1. sınıf Türkçe ders kitabında kullanılmıştır. Benzer şekilde özel yayınevlerine ait ders kitaplarında ikna edici konuşma stratejisine yer verilmediği görülmektedir. Programda da ikna edici konuşmaya bir strateji olarak sadece 8. sınıf düzeyinde yer verilmiştir. Dolayısıyla ikna edici konuşma stratejisinin sadece 8. sınıf ders kitaplarında yer alması normal olarak kabul edilebilir.

Konuşma stratejilerinin çeşitliliği açısından MEB yayınevine ait kitaplar içerisinde $5 . \operatorname{sın} ı f(f=9)$, 6. $\sin ı f(f=9), 7$. $\sin ı f(f=8)$ ve 8 . $\sin ı f(f=8)$; özel yayınevlerine ait ders kitapları arasında ise 7. $\sin ı f(f=9)$, 4. sınıf $(f=8)$, 5. sınıf $(f=7)$ ve 6. sınıf $(f=8)$ ders kitapları öne çıkmaktadır. Daha az çeşit konuşma stratejisi kullanan ders kitaplarıysa hem MEB'de hem de özel yayınevlerinde 1. sınıf Türkçe ders kitapları olmuştur. Bu bağlamda MEB'e ait 1. sınıf ders kitabında kullanılan konuşma stratejisi çeşidi 5 , özel yayınevine ait 1 . sınıf ders kitabındaysa kullanılan konuşma stratejisi çeşidi 2'dir.

Tablo 4.

Yazma Stratejilerinin Sınıf Seviyeleri Bakımından Yayınevlerine Göre Dağılımı

\begin{tabular}{|c|c|c|c|c|c|c|c|c|c|c|c|c|c|c|c|c|c|c|c|}
\hline \multirow{2}{*}{$\begin{array}{l}\text { Yazma } \\
\text { Stratejileri }\end{array}$} & \multirow{2}{*}{$\begin{array}{l}\mathrm{f} / \\
\%\end{array}$} & \multicolumn{9}{|c|}{$\begin{array}{l}\text { MEB Yayınları } \\
\text { Sınıflar }\end{array}$} & \multicolumn{9}{|c|}{$\begin{array}{l}\text { Özel Yayınevleri } \\
\text { Sınıflar }\end{array}$} \\
\hline & & 1 & 2 & 3 & 4 & 5 & 6 & 7 & 8 & $T$ & 1 & 2 & 3 & 4 & 5 & 6 & 7 & 8 & $T$ \\
\hline \multirow{2}{*}{ Not alma } & $f$ & - & - & - & - & - & - & 2 & 1 & 3 & - & - & - & - & 4 & 1 & 2 & - & 7 \\
\hline & $\%$ & - & - & - & - & - & - & 2 & 1 & 0,4 & - & - & - & - & 4 & 1 & 2 & - & 1 \\
\hline \multirow{2}{*}{ Özet çıkarma } & $f$ & - & - & - & - & 3 & 4 & 5 & 7 & 19 & - & - & - & - & 1 & 1 & - & - & 2 \\
\hline & $\%$ & - & - & - & - & 4 & 3 & 4 & 6 & 3 & - & - & - & - & 1 & 1 & - & - & 0,3 \\
\hline \multirow{2}{*}{$\begin{array}{l}\text { Boşluk } \\
\text { doldurma }\end{array}$} & $f$ & 5 & - & - & 2 & 10 & 29 & 33 & 39 & 118 & 26 & 19 & 16 & 15 & 20 & 23 & 22 & - & 141 \\
\hline & $\%$ & 12 & - & - & 3 & 12 & 24 & 30 & 32 & 19 & 36 & 30 & 28 & 20 & 22 & 25 & 22 & - & 26 \\
\hline \multirow{2}{*}{$\begin{array}{l}\text { Kelime/ kavram } \\
\text { havuzundan } \\
\text { seçerek yazma }\end{array}$} & $f$ & 1 & - & 1 & 2 & 5 & 8 & 7 & 4 & 28 & 1 & - & 2 & 3 & 2 & 2 & - & - & 10 \\
\hline & $\%$ & 2 & - & 2 & 3 & 6 & 6 & 7 & 3 & 5 & 1 & - & 3 & 4 & 2 & 2 & - & - & 2 \\
\hline \multirow{2}{*}{ Serbest yazma } & $f$ & 3 & - & 2 & 1 & - & - & 1 & - & 7 & 1 & - & 2 & 2 & - & - & 1 & - & 6 \\
\hline & $\%$ & 7 & - & 3 & 1 & - & - & 1 & - & 1 & 1 & - & 3 & 3 & - & - & 1 & - & 1 \\
\hline \multirow{2}{*}{ Kontrollü yazma } & $f$ & 5 & - & 8 & 14 & 7 & 3 & 6 & 1 & 44 & 7 & 8 & 2 & 8 & 12 & 7 & 9 & - & 53 \\
\hline & $\%$ & 12 & - & 12 & 19 & 9 & 2 & 6 & 1 & 7 & 10 & 12 & 3 & 11 & 13 & 8 & 9 & - & 10 \\
\hline \multirow{2}{*}{ Güdümlü yazma } & $f$ & - & - & - & - & - & - & 1 & - & 1 & - & - & - & 1 & - & - & 11 & - & 12 \\
\hline & $\%$ & - & - & - & - & - & - & 1 & - & 0,1 & - & - & - & 1 & - & - & 11 & - & 0,1 \\
\hline \multirow{2}{*}{ Yaratıcı yazma } & $f$ & 12 & - & 24 & 15 & 13 & 24 & 15 & 15 & 118 & 13 & 17 & 11 & 15 & 14 & 16 & 18 & - & 104 \\
\hline & $\%$ & 29 & - & 36 & 20 & 16 & 20 & 14 & 12 & 19 & 18 & 27 & 19 & 20 & 15 & 17 & 18 & - & 19 \\
\hline \multirow{2}{*}{$\begin{array}{l}\text { Metin } \\
\text { tamamlama }\end{array}$} & $f$ & 1 & - & 1 & - & 7 & 6 & 1 & 3 & 19 & 4 & - & 2 & 6 & 7 & 5 & 3 & - & 27 \\
\hline & $\%$ & 2 & - & 2 & - & 9 & 5 & 1 & 2 & 3 & 5 & - & 3 & 8 & 8 & 5 & 3 & - & 5 \\
\hline \multirow{2}{*}{$\begin{array}{l}\text { Tahminde } \\
\text { bulunma }\end{array}$} & $f$ & 5 & - & - & - & - & 1 & - & 2 & 8 & 5 & - & - & - & - & 2 & 3 & - & 10 \\
\hline & $\%$ & 12 & - & - & - & - & 1 & - & 2 & 1 & 7 & - & - & - & - & 2 & 3 & - & 2 \\
\hline \multirow{2}{*}{$\begin{array}{l}\text { Metni yeniden } \\
\text { yazma }\end{array}$} & $f$ & - & - & - & - & - & 1 & - & - & 1 & - & - & - & - & - & - & - & - & - \\
\hline & $\%$ & - & - & - & - & - & 1 & - & - & 0,1 & - & - & - & - & - & - & - & - & - \\
\hline \multirow{2}{*}{$\begin{array}{l}\text { Metinden } \\
\text { hareketle yeni } \\
\text { metin yazma }\end{array}$} & $f$ & - & - & - & - & 3 & 5 & 3 & 5 & 16 & 1 & - & - & - & - & 4 & 2 & - & 7 \\
\hline & $\%$ & - & - & - & - & 4 & 4 & 3 & 4 & 3 & 1 & - & - & - & - & 4 & 2 & - & 1 \\
\hline \multirow{2}{*}{$\begin{array}{l}\text { Duyulardan } \\
\text { hareketle } \\
\text { yazma }\end{array}$} & $f$ & - & - & - & - & 1 & - & - & - & 1 & - & - & - & - & - & - & - & - & - \\
\hline & $\%$ & - & - & - & - & 1 & - & - & - & 0,1 & - & - & - & - & - & - & - & - & - \\
\hline \multirow{2}{*}{ Planlı yazma } & $f$ & 1 & - & 2 & 4 & 5 & 5 & 5 & 4 & 26 & - & 1 & - & 2 & 2 & - & 1 & - & 6 \\
\hline & $\%$ & 2 & - & 3 & 5 & 6 & 4 & 4 & 3 & 4 & - & 2 & - & 3 & 2 & - & 1 & - & 1 \\
\hline \multirow{2}{*}{ Eleştirel yazma } & $f$ & - & - & 4 & 9 & 3 & 3 & 4 & 11 & 34 & 1 & - & 2 & 2 & 1 & 1 & 5 & - & 12 \\
\hline & $\%$ & - & - & 6 & 12 & 4 & 2 & 4 & 9 & 6 & 1 & - & 3 & 3 & 1 & 1 & 5 & - & 2 \\
\hline \multirow{2}{*}{$\begin{array}{l}\text { Betimleyici } \\
\text { yazma }\end{array}$} & $f$ & - & - & 1 & - & - & 3 & 2 & 1 & 7 & - & 1 & - & 1 & - & - & 1 & - & 3 \\
\hline & $\%$ & - & - & 2 & - & - & 2 & 2 & 1 & 1 & - & 2 & - & 1 & - & - & 1 & - & 0,5 \\
\hline Hikâye edici & $f$ & 1 & - & 1 & 1 & 3 & 7 & 4 & 5 & 22 & - & - & 3 & 5 & 3 & 2 & 1 & - & 14 \\
\hline yazma & $\%$ & 2 & - & 2 & 1 & 4 & 6 & 4 & 4 & 4 & - & - & 5 & 6 & 3 & 2 & 1 & - & 3 \\
\hline sırası & $f$ & - & - & 5 & 1 & 2 & - & - & - & 8 & - & - & 3 & - & - & 2 & 2 & - & 7 \\
\hline $\begin{array}{l}\text { karışık } \\
\text { cümlelerden }\end{array}$ & $\%$ & - & - & 7 & 1 & 2 & - & - & - & 1 & - & - & 5 & - & - & 2 & 2 & - & 1 \\
\hline
\end{tabular}


Anlatma Becerileri Kapsamında 1-8. Sınıf Türkçe Ders Kitaplarına Bir Bakış: Konuşma ve Yazma Stratejilerinin Kullanımı

\begin{tabular}{|c|c|c|c|c|c|c|c|c|c|c|c|c|c|c|c|c|c|c|c|}
\hline etin yazma & & & & & & & & & & & & & & & & & & & \\
\hline \multirow{2}{*}{$\begin{array}{l}\text { Hikâyenin } \\
\text { ortasını yazma }\end{array}$} & $f$ & - & - & - & - & - & - & - & - & - & - & - & - & - & - & - & - & - & - \\
\hline & $\%$ & - & - & - & - & - & - & - & - & - & - & - & - & - & - & - & - & - & - \\
\hline \multirow{2}{*}{$\begin{array}{ll}\text { Şikâyet } & \text { yazısı } \\
\text { yazma } & \\
\end{array}$} & $f$ & - & - & - & - & - & - & - & - & - & - & - & - & - & - & - & - & - & - \\
\hline & $\%$ & - & - & - & - & - & - & - & - & - & - & - & - & - & - & - & - & - & - \\
\hline \multirow{2}{*}{$\begin{array}{l}\text { Karşılaştırmalı } \\
\text { yazma }\end{array}$} & $f$ & - & - & - & 5 & 2 & 1 & 5 & 4 & 17 & - & 4 & 2 & 2 & 2 & 1 & - & - & 11 \\
\hline & $\%$ & - & - & - & 7 & 2 & 1 & 4 & 3 & 3 & - & 6 & 3 & 3 & 2 & 1 & - & - & 2 \\
\hline \multirow{2}{*}{$\begin{array}{l}\text { İş birliği yaparak } \\
\text { (paylaşarak) } \\
\text { yazma }\end{array}$} & $f$ & - & - & - & - & 2 & 1 & - & 1 & 4 & - & - & - & - & 1 & - & - & - & 1 \\
\hline & $\%$ & - & - & - & - & 2 & 1 & - & 1 & 0,6 & - & - & - & - & 1 & - & - & - & 0,1 \\
\hline \multirow{2}{*}{$\begin{array}{l}\text { Empati kurarak } \\
\text { yazma }\end{array}$} & $f$ & - & - & - & 1 & 2 & 8 & 6 & 4 & 21 & 2 & 1 & 2 & 1 & 6 & 5 & - & - & 17 \\
\hline & $\%$ & - & - & - & 1 & 2 & 6 & 6 & 3 & 3 & 3 & 2 & 3 & 1 & 7 & 5 & - & - & 3 \\
\hline \multirow{2}{*}{$\begin{array}{l}\text { Reklam } \\
\text { yazma }\end{array}$} & $f$ & - & - & - & - & - & 1 & - & - & 1 & - & - & - & - & 1 & - & - & - & 1 \\
\hline & $\%$ & - & - & - & - & - & 1 & - & - & 0,1 & - & - & - & - & 1 & - & - & - & 0,1 \\
\hline \multirow{2}{*}{ Dikte } & $f$ & 3 & - & - & - & - & - & - & - & 3 & 4 & 3 & 4 & - & - & - & - & - & 11 \\
\hline & $\%$ & 7 & - & - & - & - & - & - & - & 0,4 & 5 & 5 & 7 & - & - & - & - & - & 2 \\
\hline \multirow{2}{*}{$\begin{array}{l}\text { Görsellerden } \\
\text { hareketle } \\
\text { yazma }\end{array}$} & $f$ & 5 & - & 4 & 7 & 8 & 3 & - & 5 & 32 & 7 & 7 & 6 & 8 & 9 & 7 & 5 & - & 49 \\
\hline & $\%$ & 12 & - & 6 & 9 & 10 & 2 & - & 4 & 5 & 10 & 11 & 10 & 11 & 10 & 8 & 5 & - & 9 \\
\hline \multirow{2}{*}{ Bakarak yazma } & $f$ & - & - & 1 & 8 & - & - & - & - & 9 & - & - & - & - & - & - & - & - & - \\
\hline & $\%$ & - & - & 2 & 11 & - & - & - & - & 1 & - & - & - & - & - & - & - & - & - \\
\hline \multirow{2}{*}{$\begin{array}{l}\text { Geleneksel } \\
\text { yazma }\end{array}$} & $f$ & - & - & 11 & 4 & 2 & 8 & 5 & 4 & 34 & 1 & 2 & 1 & 4 & 5 & 9 & 8 & - & 30 \\
\hline & $\%$ & - & - & 16 & 5 & 2 & 7 & 4 & 3 & 6 & 1 & 3 & 2 & 5 & 5 & 10 & 8 & - & 5 \\
\hline \multirow{2}{*}{$\begin{array}{l}\text { Bilgilendirici } \\
\text { yazma }\end{array}$} & $f$ & - & - & 1 & 1 & 3 & 2 & 3 & 7 & 17 & - & - & - & - & 2 & 5 & 7 & - & 14 \\
\hline & $\%$ & - & - & 2 & 1 & 4 & 2 & 3 & 6 & 3 & - & - & - & - & 2 & 5 & 7 & - & 3 \\
\hline \multirow[t]{2}{*}{ TOPLAM } & $f$ & 42 & - & 66 & 75 & 81 & 123 & 108 & 123 & 618 & 73 & 63 & 58 & 75 & 92 & 93 & 101 & - & 555 \\
\hline & $\%$ & 7 & - & 11 & 12 & 13 & 20 & 17 & 20 & 100 & 13 & 11 & 10 & 14 & 17 & 17 & 18 & - & 100 \\
\hline
\end{tabular}

Tablo 4'e göre 1-8. sınıflar arası, MEB tarafından basılmış Türkçe ders kitaplarında 618, özel yayınevleri tarafından basılmış Türkçe ders kitaplarında 555 yazma stratejisi tespit edilmiştir. MEB kitaplarında yazma stratejilerine en çok yer veren ders kitabı 6. $\operatorname{sınıf~}(f=123)$ ve 8 . sınıf $(f=123)$ ders kitaplarıdır. Bunu 7. sınıf $(f=108)$ ve 5. sınıf $(f=81)$ ders kitapları izlemektedir. Özel yayınevlerine ait kitaplar içinde yazma stratejilerine en fazla yer veren ders kitabıysa 7. sınıf ders kitabıdır ( $f=101)$. Bunu sırasıyla 6. sınıf $(f=93)$ ve 5 . sınıf ders kitapları $(f=92)$ izlemektedir. MEB yayınevine ait ders kitaplarında yazma stratejileri sınıf seviyeleri bakımından 1. sınıftan 8. sınıfa dek nispeten sistematik bir artış eğiliminde olsa da özel yayınevlerine ait ders kitaplarında böyle bir artış ve azalma görülmemektedir.

MEB yayınlarından çıkan Türkçe ders kitapları içinde en fazla kullanılan yazma stratejisi boşluk doldurmadır (\%19). Bunu sırasıyla yaratıcı yazma (\%19), kontrollü yazma (\%7), eleştirel yazma (\%6) ve geleneksel yazma (\%6) izlemektedir. Özel yayınevlerine ait Türkçe ders kitapları içinde en çok kullanılan yazma stratejisi ise yine boşluk doldurmadır (\%26). Ardından yaratıcı yazma (\%19), kontrollü yazma (\%10), görsellerden hareketle yazma (\%9), metin tamamlama (\%5) ve geleneksel yazma (\%5) gelmektedir. Hem MEB kitapları hem de özel yayınevlerine ait ders kitaplarında en çok kullanılan yazma stratejilerinin sırası benzerlik göstermektedir. Buna göre her iki yayınevi grubunda da en çok kullanılan yazma stratejileri boşluk doldurma, yaratıcı yazma ve kontrollü yazma olmuştur. Bu durumun TDÖP ile uyumluluk arz ettiği söylenebilir.

MEB yayınevine ait Türkçe ders kitaplarında sınıf seviyeleri açısından en sık başvurulan yazma stratejilerine bakıldığında boşluk doldurma stratejisinin en çok 8. sınıf (\%32), 7. sınıf (\%30) ve 6. sınıf (\%29); yaratıcı yazma stratejisinin en çok 3. sınıf (\%36), 1. sınıf (\%29), 6. sınıf (\%20) ve 4. sınıf (\%20); kontrollü yazma stratejisinin en çok 4.sınıf (\%19), 3. sınıf (\%12) ve 1. sınıf (\%12); eleştirel yazma stratejisinin en çok 4. sınıf (\%12) ve 8. sınıf (\%9); geleneksel yazma stratejisinin en çok 3. sınıf (\%16) ve 6. sınıf (\%7) ders kitaplarında kullanıldığı tespit edilmiştir. Özel yayınevlerinin hazırladığı Türkçe ders kitaplarında daha sık başvurulan yazma stratejilerine sınıf bazında bakıldığında boşluk doldurma stratejisinin en çok 1 . sınıf (\%36), 2. sınıf (\%30) ve 3. sınıf (\%28); yaratıcı yazma stratejisinin 2. sınıf (\%27), 4. sınıf (\%20) ve 3. sınıf (\%19); kontrollü yazma stratejisinin 5. sınıf (\%13), 2. sınıf (\%12) ve 4. 
sınıf (\%11); görsellerden hareketle yazma stratejisinin 4. sınıf (\%11) ve 2. sınıf (\%11); metin tamamlama stratejisinin 5. sınıf (\%8) ve 4. sınıf (\%8); geleneksel yazma stratejisinin 6. sınıf (\%10) ve 7. sınıfta (\%8) kullanıldığı görülmüştür. Bu bulguların sınıf seviyelerine göre anlamlı bir değişiklik göstermediği dikkat çeken bir bulgudur.

Tablo 4'e göre MEB yayınevine ait Türkçe ders kitaplarında hikâyenin ortasını yazma, şikâyet yazısı yazma stratejilerine yer verilmemiştir. Bununla birlikte not alma stratejisinin sadece 7 . ve 8 . sınıflarda, güdümlü yazmanın 7. sınıfta, metni yeniden yazmanın 6. sınıfta, duyulardan hareketle yazmanın 5. sınıfta, diktenin 1. sınıfta, bakarak yazmanınsa sadece 3. ve 4. sınıfta kullanıldığını görmek mümkündür. Özel yayınevleri tarafından hazırlanan Türkçe ders kitaplarındaysa metni yeniden yazma, duyulardan hareketle yazma, hikâyenin ortasını yazma ve bakarak yazma stratejilerinin kullanılmadığı görülmektedir. Bunun yanında not almanın 5, 6, ve 7. sınıfta, özet çıkarmanın 5. ve 6. sınıfta, diktenin 1, 2. ve 3. sınıfta kullanılması dikkat çeken diğer sonuçlardandır. Bu durum TDÖP ile uyumlu bir sonuç arz etmektedir. Çünkü adı geçen stratejilerin öğretim programında belirtilen sınıf düzeylerinde kullanılması tavsiye edilmiştir.

MEB yayınevinden çıkan ve incelemeye esas tüm Türkçe ders kitapları içinde, kullanılan yazma stratejilerinin çeşitliliği bakımından 6. $\operatorname{sın} ı f(f=20), 8$. $\sin ı f(f=19), 5 . \operatorname{sın} ı f(f=18)$ ve 7. $\operatorname{sın} ı f(f=18)$; özel yayınevlerinden çıkan kitaplar içinde 5. sınıf $(f=17), 6$. sınıf $(f=17)$ ve 7. sınıf $(f=17)$ ders kitapları öne çıkmaktadır. Daha az çeşit yazma stratejisi kullanan ders kitaplarıysa MEB yayınevinde 11 farklı stratejiyle 1 . sınıf, özel yayınevlerinde 10 farklı yazma stratejisiyle 2 . sınıf Türkçe ders kitabı olmuştur.

\section{Tartışma ve Sonuç}

Bu araştırmada 2019-2020 eğitim-öğretim yılında 1-8. sınıflarda okutulmakta olan MEB ve özel yayınevlerine ait Türkçe ders kitaplarında konuşma ve yazma stratejilerinin dağılımı incelenmiştir. Araştırmanın sonucunda MEB tarafından basılmış Türkçe ders kitaplarında 493, özel yayınevleri tarafından basılmış Türkçe ders kitaplarında 357 konuşma stratejisi tespit edilmiştir. MEB kitaplarında en fazla konuşma stratejisine yer veren ders kitapları sırasıyla $6,7,8$ ve 5 . sınıf ders kitaplarıdır. Özel yayınevlerine ait kitaplar içinde konuşma stratejisine en fazla yer veren ders kitabı ise 6, 2 ve 5. sınıf ders kitaplarıdır. Her iki yayınevine ait ders kitaplarında konuşma stratejilerinin sınıf seviyeleri bakımından sistematik bir artı̧ veya azalma göstermediği görülmektedir. Benzer şekilde Şimşek ve Demirel (2020) ile Deniz, Karagöl ve Tarakçı (2019), inceledikleri Türkçe ders kitaplarında konuşma stratejilerinin yeterli ve dengeli bir dağılım göstermediğini tespit etmişlerdir. Bu sonuçların aksine Temizkan (2013), 2005 yılına ait 7. sınıf Türkçe ders kitaplarındaki yazma etkinliklerini incelediği çalışmasında kitaplarda yer alan yazma stratejilerinin nitelik ve nicelik olarak kısmen yeterli ve faydalı olduğu sonucuna ulaşmıştır. Ders kitaplarının niteliğinin yıldan yıla farklılık göstermesi ise; öğretim programının değişmesi, kılavuz kitap uygulamasının kaldırılması ve öğretmen yetiştirme programlarının güncellenmesi gibi nedenlerle açıklanabilir.

Bu çalışmada MEB'e ait ders kitapları içinde en fazla kullanılan konuşma stratejisinin serbest konuşma olduğu bunu sırasıyla planlı/hazırlıklı konuşma, yaratıcı konuşma, tartışma, empati kurarak konuşmanın izlediği belirlenmiştir. Dolayısıyla MEB yayınlarında empati kurarak konuşmanın bir strateji olarak ihmal edildiği görülmektedir. Bu sonuç, Sağlam ve Yüksel'in (2019) empati kurarak dinleme etkinliklerinin MEB yayınları 7. sınıf Türkçe ders kitabında yeterli nitelik ve nicelikte olmadığını ortaya koyduğu çalışmalarının sonuçlarıyla örtüşmektedir. Bu araştırmada dikkat çeken başka bir sonuç, hazırlıklı konuşmanın MEB yayınlarına ait kitaplarda en çok kullanılan strateji olmasıdır. Nitekim Benzer ve Ünsal da (2019) Türkçe Dersi Öğretim Programı'nda belirtilen yöntem ve tekniklerle ilgili öğretmen görüşlerinden elde ettikleri bulgular ışığında öğretmenler tarafından en çok hazırlıklı ve katılımlı konuşma ile tartışma stratejilerinin kullanıldığını tespit etmişlerdir. Bu farkılık, programın uygulayıcıları konumunda olan öğretmenlerin ders kitaplarına bağlı kalmadan kendi etkinliklerini uygulamaları ile açıklanabilir. Zira ders kitapları, öğrenme-öğretme sürecinde başat materyallerden olmasına karşın öğretmen, ders kitabına birebir bağıı kalmadan kendi etkinliklerini uygulayabilir.

Bu çalışmada, özel yayınevlerine ait Türkçe ders kitapları içinde en çok kullanılan konuşma stratejilerinin sırasıyla serbest konuşma, yaratıcı konuşma, planlı/hazırlıklı konuşma, tartışma, empati 
kurarak konuşma olduğu sonucuna ulaşılmıştır. Hem MEB hem de özel yayınevlerine ait ders kitaplarında en çok kullanılan konuşma stratejilerinin sıralaması benzerlik göstermektedir. Buna göre her iki yayınevine ait kitaplarda en çok kullanılan konuşma stratejisi serbest konuşma olmuştur. Bu sonuçlar, Coşkun ve Narinç'in (2018) MEB yayınları 5. sınıf Türkçe ders kitabında en çok yer verilen konuşma stratejisinin kendisini karşısındakinin yerine koyarak (empati kurarak) konuşma ve serbest konuşma stratejilerinin olduğu sonucuyla benzerlik göstermektedir. Benzer şekilde Yıldız ve Asma (2020), Cumhuriyet'ten günümüze kadar inceledikleri Türkçe dersine ait öğretim programlarında en çok yer verilen konuşma stratejisinin serbest konuşma olduğunu tespit etmişlerdir. Ders kitapları, öğretim programları esas alınarak hazırlandığı için bu sonucun olağan olduğu söylenebilir. Ayrıca Şahin ve Şimşek de (2020) çalışmalarında, 7. sınıf Türkçe ders kitaplarında en çok serbest konuşma stratejisinin kullanıldığını tespit etmişlerdir. Bu araştırma kapsamında da incelenen ders kitaplarında da en çok kullanılan konuşma stratejisinin serbest konuşma olması birbirini destekler nitelikte sonuçlardır.

$\mathrm{Bu}$ araştırmada dikkat çeken başka bir sonuç, ikna edici konuşma türüne MEB ve özel yayınevlerine ait ders kitaplarında hemen hemen hiç yer verilmemiş olmasıdır. TDÖP'de ikna edici konuşmaya bir strateji olarak sadece 8. sınıf düzeyinde yer verilmiştir. Dolayısıyla bu durumun beklenebilir bir sonuç olduğunu söylemek mümkündür. Incelenen kitaplarda yalnızca MEB'e ait 8. sınıf Türkçe ders kitabında sadece bir adet ikna edici konuşma etkinliğine yer verildiği görülmektedir. Bu sonuç; Okur, Süğümlü ve Göçen'in (2013) araştırmalarının sonuçlarıyla benzerlik göstermektedir.

Sınıf seviyeleri açısından konuşma stratejilerinin kullanımını tespit etmek, bu araştırmanın bir diğer amacıdır. MEB yayınevine ait Türkçe ders kitaplarında sınıf seviyeleri açısından en sık başvurulan konuşma stratejilerine bakıldı̆̆ında serbest konuşma stratejisinin en çok ilk kademe (ilkokul) ders kitaplarında; planlı/hazırıklı konuşma stratejisinin ise en çok ikinci kademe (ortaokul) kitaplarında kullanıldığı dikkat çekmektedir. Benzer şekilde özel yayınevlerine ait ders kitaplarında da serbest konuşma stratejilerine en çok ilkokul düzeyinde yer verildiği dikkat çekmektedir. Ayrıca her iki yayınevine ait kitaplarda yaratıcı konuşma stratejisinin sınıf seviyelerine göre dağııımda bir bütünlük olmadığı görülmekle birlikte tartışma stratejisinin en çok ilkokul düzeyinde; empati kurarak konuşma stratejisinin en çok ortaokul düzeyinde kullanıldığı görülmektedir.

Araştırmanın bir başka sonucu, her iki yayınevine ait Türkçe ders kitaplarında bir konuşma stratejisi olarak hafızada tutmaya çok az $(\mathfrak{f}=3)$ yer verilmesidir. Bunun nedeninin bu strateji hakkında öğretmen ve ders kitabı yazarlarının yeterince bilgi sahibi olmayışı ve bu stratejiye öğretim programında sadece 6. sınıf düzeyinde yer verilmesi olduğu söylenebilir. Ayrıca güdümlü konuşma stratejisine sadece MEB 1. sınıf Türkçe ders kitabında yer verilmiş olması da dikkat çekici başka bir sonuçtur.

Konuşma stratejilerinin çeşitliliği açısından MEB'e ait kitaplar içerisinde 5, 6, 7 ve 8. sınıflar ön plana çıkarken özel yayınevlerine ait ders kitapları arasında 7, 4, 5 ve 6. sınıf kitapları öne çıkmaktadır. Daha az çeşit konuşma stratejisi kullanılan ders kitaplarıysa hem MEB hem de özel yayınevlerinde 1. sınıf Türkçe ders kitapları olmuştur. Bu bağlamda MEB'e ait 1. sınıf ders kitabında kullanılan konuşma stratejisi çeşidi 5, özel yayınevine ait 1 . sınıf ders kitabındaysa kullanılan konuşma stratejisi çeşidi 2'dir. Bu durum, birinci sınıfta ilk dönem ilk okuma yazma çalışmalarına ağırlık verilmesiyle açıklanabilir. Nitekim ilkokul 1. sınıf ders kitaplarında 4 tema bulunmaktayken diğer sınıf düzeylerinde 8 tema yer almaktadır.

Bu araştırmanın diğer bir boyutu da yazma stratejilerinin MEB ve özel yayınevlerine göre dağılımını ortaya koymaktır. Bu açıdan araştırmanın sonuçlarına göre, 1-8. sınıflar arası MEB tarafından basılmış tüm Türkçe ders kitaplarında 618, özel yayınevleri tarından basılmış Türkçe ders kitaplarında 555 yazma stratejisi tespit edilmiştir. Zenginlik açısından MEB tarafından yayımlanan kitapların daha fazla strateji içerdiği dikkat çekmektedir. MEB kitaplarında yazma stratejilerine en çok yer veren ders kitapları sırasıyla 6, 8 ve 7. sınıf ders kitaplarıdır. Özel yayınevlerine ait kitaplar içinde yazma stratejilerine en fazla yer veren ders kitabı ise 7, 6 ve 5 . sınıf ders kitaplarıdır. MEB yayınevine ait ders kitaplarında yazma stratejileri sınıf seviyeleri bakımından 1. sınıftan 8. sınıfa dek nispeten sistematik bir artış eğiliminde olsa da özel yayınevlerine ait ders kitaplarında böyle bir artış ya da 
azalış görülmemektedir. Bu sonuçlara benzer şekilde Karagöl ve Tarakçı (2018) ile Şimşek ve Demirel (2020) de yazma kazanımlarının Türkçe ders kitaplarında yeterli ve dengeli bir şekilde dağılmadığı sonucuna ulaşmışlardır.

MEB ve özel yayınevleri tarafından yayımlanan Türkçe ders kitapları içinde en fazla kullanılan yazma stratejileri boşluk doldurma, yaratıcı yazma ve kontrollü yazmadır. Coşkun ve Narinç'e (2018) göre ise MEB 5. sınıf Türkçe ders kitabında en çok kullanılan yazma stratejisi metin tamamlamadır. Şahin ve Şimşek'e göre de (2020), 7. sınıf Türkçe ders kitaplarında en çok kullanılan yazma stratejisi bir metinden hareketle yazmadır. Metin tamamlama ve bir metinden hareketle yazma etkinliklerinin de yaratıcı yazma kapsamında değerlendirilmesinin yanlış olmadığı düşünüldüğünde bu sonuçların araştırmamızın sonuçlarıyla çelişmediği görülmektedir. Bunun yanı sıra geleneksel yazmanın da yaratıcı yazmanın zıttı olarak ders kitaplarında yer aldığını söylemek mümkündür. Yazma eğitiminde temel olarak bir atasözü, deyim ya da özdeyiş açıklatma kapsamında değerlendirilen geleneksel yazma stratejisine ders kitaplarında fazla yer verilmemelidir. Nitekim henüz yazmayı alışkanlık hâline getirememiş öğrenciler için geleneksel yazma yaklaşımlarının kullanılması monotonluğa ve motivasyon kaybına neden olmaktadır. Bununla birlikte ders kitaplarında yaratıcı yazma stratejisine geleneksel yazmadan daha fazla yer verildiği tespit edilmiştir. Bu durumun TDÖP ile uyumlu olduğu söylenebilir.

Bu çalışmada, kullanılan yazma stratejilerinin çeşitliliği bakımından MEB yayınlarından 6, 8, 5 ve 7. sınıf; özel yayınevlerinden ise 5,6 ve 7. sınıf ders kitapları öne çıkmaktadır. Her iki yayınevi açısından bakıldığında 1 ve 2 . sınıf düzeyinde daha az yazma stratejisine yer verildiği dikkat çekmektedir. Bu durum, öğrencilerin ilk okuma yazma sürecinde olmalarıyla açıklanabilir.

Çalışmanın sonucunda anlatma becerileri kapsamında değerlendirilen konuşma ve yazma stratejilerinin 1-8. sınıf Türkçe ders kitaplarında yeterli ve dengeli bir dağılım göstermediği ortaya çıkmıştır. Marangoz (2014), 2006 Türkçe Dersi Öğretim Programı'na göre hazırlanan Türkçe ders kitaplarındaki konuşma etkinliklerini incelediği araştırmasında; 6, 7 ve 8. sınıf Türkçe ders kitaplarının konuşma becerisini geliştirmede yetersiz kaldığı sonucuna ulaşmıştır. Bu örtüşen sonuçlar, ders kitaplarının niteliğinin programlara ve yıllara göre bir gelişim göstermediğini ortaya koymaktadır. Öğrencilerin kendilerini yazılı ve sözlü olarak ifade etme becerisini geliştirmeyi amaçlayan Türkçe derslerinde motivasyonu sağlamak, dikkat çekmek, farklı gereksinimleri olan öğrencilere hitap etmek ve dersi monotonluktan kurtarmak için konuşma ve yazma etkinlikleri kapsamında farklı ve çok strateji kullanmak gereklidir.

\section{Öneriler}

Çalışmanın sonucunda ders kitaplarında kullanılan konuşma ve yazma stratejilerinin sınıf düzeylerine ve yayınevlerine göre yeterli ve dengeli dağılım göstermediği tespit edilmiştir. Bu sonuç TDÖP'de yer verilen stratejilerin hangi sınıf düzeyinde kullanılması gerektiği ile ilgili bilgilerin yetersiz oluşu ile açıklanabilir. Bu nedenle TDÖP hazırlanırken konuşma ve yazma stratejilerinin sınıf seviyelerine dağııımı açısından bir denge gözetilerek hazırlanması önerilmektedir.

Ders kitapları hazırlanırken özellikle yazarlar tarafından konuşma ve yazma stratejilerinin dengeli dağılımına özen gösterilmelidir. Neticede kitap yazarları için TDÖP bir belirleyici olsa da strateji/yöntem seçimi yazarın inisifiyatine bırakılmıştır. Ders kitaplarının da öğrenme-öğretme sürecinde en çok kullanılan materyal olduğu göz önünde bulundurulduğunda kitap yazarlarının bu duruma dikkat etmesi gerektiği önerilmektedir.

Ders kitaplarına konacak metinlerin çeşitli konuşma ve yazma stratejilerini kullanmaya olanak verecek nitelikte seçilmesi önerilmektedir.

Incelenen kitaplarda yaratıcı ve eleştirel düşünmeyi ön plana çıkaran stratejiler yanında özlü söz, atasözü ve deyim açıklatmaya yönelik geleneksel tarzdaki konuşma ve yazma stratejilerine yer verildiği tespit edilmiştir. Yazma ve konuşma eğitiminin başarıya ulaşabilmesi için ders kitaplarında strateji olarak geleneksel yaklaşımlar yerine mümkün olduğunca yaratıcı ve çağdaş yaklaşımlara yer verilmesi gerektiği önerilmektedir. 
Anlatma Becerileri Kapsamında 1-8. Sınıf Türkçe Ders Kitaplarına Bir Bakış: Konuşma ve Yazma Stratejilerinin Kullanımı

Bu araştırma, ders kitaplarındaki konuşma ve yazma stratejilerinin tespit edilmesine yöneliktir. Diğer araştırmacılara da ders kitaplarındaki okuma ve dinleme stratejilerinin de ne düzeyde kullanıldığının tespitine yönelik araştırmalar yapmaları önerilebilir.

\section{Yazarların Katkı Oranı}

Makalenin hazırlanmasında 1. yazar \%60, 2. yazar \%40 oranında katkı sağlamıştır.

\section{Çıkar Çatışması}

Bu araştırmada çıkar çatışması teşkil edebilecek herhangi bir durum ya da ilişki yoktur.

\section{Kaynaklar}

Aktaş, Ş. ve Gündüz, O. (2008). Yazılı ve sözlü anlatım-kompozisyon sanatı. Ankara: Akçağ Yayınları. Akyol, H. (2006). Yeni programa uygun Türkçe öğretim yöntemleri. Ankara: Kök Yayıncılık.

Arıcı, A. F. ve Ungan, S. (2008). İlköğretim ikinci kademe öğrencilerinin yazılı anlatım çalışmalarının bazı yönlerden değerlendirilmesi. Dumlupınar Üniversitesi Sosyal Bilimler Dergisi, 20, 317- 328.

Başaran, M. ve Erdem, İ. (2009). Öğretmen adaylarının güzel konuşma becerisi ile ilgili görüşleri üzerine bir araştırma. Kastamonu Eğitim Dergisi, 17 (3), 743-754.

Benzer, A. ve Ünsal, F. (2019). Konuşma öğretiminin program ve ders kitabı ekseninde uygulamaya yansıması. Ana Dili Eğitimi Dergisi, 7 (3), 647-662.

Büyükikiz, K. K. ve Hasırcı, S. (2013). Anadil eğitiminde konuşma becerisinin yeri. Okuma-Yazma Eğitimi Araştırmaları, 1 (1), 57-63.

Coşkun, H. ve Narinç F. (2018). 2017 Türkçe öğretim programı esas alınarak hazırlanan 5. Sınıf Türkçe ders kitabında yer alan yazma ve konuşma etkinliklerinin incelenmesi. Iğdır Üniversitesi Sosyal Bilimler Dergisi, 16, 627-645.

Creswell, J. W. (2016). Nitel araştırma yöntemleri: beş yaklaşıma göre nitel araştırma ve araştırma deseni. M. Bütün ve S. B. Demir (Çev. Ed.). Ankara: Siyasal Kitabevi.

Deniz, K., Karagöl, E. ve Tarakçı, R. (2019). Konuşma kazanımları açısından ortaokul Türkçe ders kitapları. Turkish Studies, 14 (4), 1257-1269.

Doğan, Y. (2009). Konuşma becerisinin geliştirilmesine yönelik etkinlik önerileri. Türk Eğitim Bilimleri Dergisi, 7 (1), 185-204.

Doğan, Y. (2013). Dinleme eğitimi. Ankara: PegemA Yayınları.

Esendemir, N. (2019). Türkçe öğretmenlerinin yazma stratejilerine ilişkin farkındalık ve görüşleri. Yayınlanmamış yüksek lisans tezi, Hacettepe Üniversitesi Eğitim Bilimleri Enstitüsü, Türkçe Eğitimi Ana Bilim Dalı, Ankara.

Göçer, A. (2010). Türkçe öğretiminde yazma eğitimi. Uluslararası Sosyal Araştırmalar Dergisi, 3 (12), 178-195.

Güfta, H. ve Zorbaz, K. Z. (2008). İlköğretim ikinci kademe Türkçe dersi yazılı sınav sorularının düzeyleri üzerine bir değerlendirme. Journal of the Cukurova University Institute of Social Sciences, 17 (2), 205-218.

Güneş, F. (2007). Türkçe öğretimi ve zihinsel yapılandırma. Ankara: Nobel Yayıncılık.

Karadağ, Ö. (2019). Türkçe ders kitaplarında yer alan özetleme etkinlikleri üzerine bir değerlendirme. Ana Dili Eğitimi Dergisi, 7 (2), 469-485.

Karagöl, E. ve Tarakçı, R. (2018). Yazma becerisi kazanımları açısından ortaokul Türkçe ders kitapları. International Journal of Languages Education, 6 (4), 87-100.

Karagöz, B. ve Şeref, i. (2020) Yazma becerisiyle ilgili makaleler üzerine bir inceleme: Web of Science veri tabanında eğilimler. Ana Dili Eğitimi Dergisi, 8 (1), 67-86.

Karatay, H. ve Aksu, Ö. (2011). 4+1 planlı yazma ve değerlendirme modelinin öğretmen adaylarının yazılı anlatım tutumlarını ve yazma becerilerini geliştirmeye etkisi. Turkish Studies, 6 (3), 10291047.

Kavcar, C., Oğuzkan, F. ve Sever, S. (1999). Türkçe öğretimi. Ankara: Engin Yayınları. 
Kurudayıoğlu, M. (2003). Konuşma eğimi ve konuşma becerisini geliştirmeye yönelik etkinlikler. Türklük Bilimi Araştırmaları, 13, 287-309.

Küçük, S. (2006). Türkçe öğretiminde yazılı anlatım çalışmalarının sorularla yönlendirilmesi. Türk Eğitim Bilimleri Dergisi, 4 (2), 181-198.

Marangoz, M. M. (2014). İlköğretim Türkçe ders kitaplarında konuşma eğitimi uygulamaları. (Yayımlanmamış Yüksek Lisans Tezi). Uşak Üniversitesi Sosyal Bilimler Enstitüsü.

MEB. (2009a). Türkçe dersi öğretim programı (1-5. Sınıflar). Ankara: MEB.

MEB. (2009b). Türkçe dersi ögretim programı (6-8. Sınıflar). Ankara: MEB.

MEB. (2019). Türkçe dersi öğretim programı (1-8. Sınıflar). Ankara: MEB.

Merriam, S. B. (2013). Nitel araştırma desen ve uygulama için bir rehber. S. Turan (Çev. Ed.), Ankara: Nobel.

Miles, M, B. and Huberman, A. M. (1994). Qualitative data analysis: An expanded sourcebook. Thousand Oaks, CA: Sage.

Okur, A., Süğümlü, Ü. ve Göçen, G. (2013). İkna edici konuşma ve karşılaştırmalı bir araştırma (Avustralya ana dili öğretimi ders materyalleri ve Türkçe örneği). Turkish Studies, 8 (8), 951970.

Patton, M. Q. (2014). Nitel araştırma ve değerlendirme yöntemleri. M. Bütün ve S. Beşir Demir (Çev. Ed.), Ankara: PegemA Yayınları.

Sağlam, M. H. ve Yüksel, A. (2019). Ortaokul Türkçe ders kitaplarında empati kurarak dinleme ve konuşma etkinlikleri üzerine bir değerlendirme çalışması. M. Kılıç, M. Eraslan (Ed.), 6. Uluslararası Multidisipliner Çalışmaları Kongre Kitabı (ss. 15-25). Elâzığ: Asos Yayınevi.

Sever, S. (2004). Türkçe öğretimi ve tam öğrenme. Ankara: Anı Yayıncılık.

Şimşek, Ş. ve Demirel, í. (2020). Ortaokul Türkçe ders kitaplarının anlatıma dayalı etkinlikler yönünden karşılaştııılması. Kastamonu Eğitim Dergisi, 28 (5), 2125-2135. DOI: 10.24106/kefdergi.731886.

Tağa, T. ve Ünlü, S. (2013). Yazma eğitiminde karşılaşılan sorunlar üzerine bir inceleme. Turkish Studies, 8 (8), 1285-1299.

Temizkan, M. (2009). Akran değerlendirmenin konuşma becerisinin geliştirilmesi üzerindeki etkisi. Mustafa Kemal Üniversitesi Sosyal Bilimler Enstitüsü Dergisi, 6 (12), 90-112.

Temizkan, M. (2013). Illköğretim 6-8. sınıf Türkçe öğretmen kılavuz kitaplarındaki yazma yöntemleri üzerine bir inceleme (MEB yayınları örneği). Dil ve Edebiyat Eğitimi Dergisi, 2 (5), 95-124.

Yalçın, A. (2002). Türkçe öğretim yöntemleri-yeni yaklaşımlar. Ankara: Akçağ Yayınları.

Yıldız, Ü. ve Asma, B. (2020). Cumhuriyet dönemi Türkçe dersi öğretim programlarında (1924-2018) dil becerilerinin öğretimde kullanılan tekniklerin incelenmesi. Kastamonu Education Journal, 28 (3), 1168-1180.

Yılmaz, F. ve Cımbız, A. T. (2016). Ortaokul Türkçe dersi konuşma becerisi üzerine bir inceleme. The Journal of Academic Social Science Studies, 49, 25-46.

\section{Introduction}

\section{Extended Abstract}

Turkish language teaching aims to improve individual's comprehension (listening, reading) and narrative (speaking and writing) skills. Individuals who develop comprehension and narrative skills at an early age can use their mother tongue accurately, effectively and smoothly. The 2019 Turkish Language Curriculum (TLC) provides a framework that integrates knowledge, skills and values that will enable students to acquire the language and cognitive skills related to listening/viewing, speaking, reading and writing which they can use for the rest of their lives. The curriculum considers the development of language skills and competencies as a prerequisite for learning, personal and social development and professional skills in all other areas (MEB, 2019: 25).

There is a skill-based approach in the curriculum based on a thematic approach. To implement the approach, activities were included in the teaching-learning process in order to realize the pre-determined goals and outcomes in the curriculum. It is possible to improve the comprehension and narrative skills of students, which are the main goals in the TLC, through activity- 
based practices. Individuals who develop comprehension and narrative skills can express themselves when they speak or write. Some strategies need to be used effectively in order to develop these skills. In the TLC, outcomes related to speaking and writing skills are defined for each grade level. Among those outcomes, the outcomes Applies writing strategies and Applies speaking strategies which are repeated in every grade level bring along the question of what the concept of strategy means and how it needs to be interpreted. Research studies reveal that teachers have low awareness of these strategies even though they have to implement them in the teaching-learning process (Esendemir, 2019).

The outcomes in the curriculum are redounded to students through some activities in the teaching-learning process. In the curriculum based on a skill and activity-based approach, linguistic areas covering listening, speaking, reading and writing skills should be taught to students through activity-based practices that reflect a holistic perspective. Considering that course books are the most frequently used teaching materials in the teaching-learning process, the problem of quality comes to the fore. Activities in the Turkish language course books prepared according to the 2019 TLC should be designed to improve students' reading, writing, speaking, listening and grammar skills. However, it should not be forgotten that these activities are recommended and that teachers can design their own activities.

A large part of academic studies on Turkish language teaching in Turkey is on textbooks. However, studies that comprehensively examine the level of usage of speaking and writing strategies in course books in terms of grade levels and publishers are limited. This study aims to fill this gap in the literature.

\section{Method}

This study aims to determine the distribution of speaking and writing strategies in Turkish language course books prepared according to the 2019 TLC in terms of grade levels and publishers. It is qualitative by design. The document analysis method was used to collect data. In the study, 14 Turkish language course books (Grades 1-8) published by the Ministry of National Education (MoNE) and private publishers were examined in terms of the distribution of speaking and writing strategies. Relevant literature was surveyed in order to determine which speaking and writing strategies were used in the course books.

\section{Result and Discussion}

493 speaking strategy activities were found in the Turkish language course books published by the MoNE and 357 speaking strategy activities were found in the course books published by private publishers. The course books that included speaking strategy activities the most were those by the MoNE, and they were the $6^{\text {th }}, 7^{\text {th }}, 8^{\text {th }}$ and $5^{\text {th }}$ grade course books respectively. In the course books by private publishers, those that included speaking strategy activities the most were the $6^{\text {th }}$, $2^{\text {nd }}$ and $5^{\text {th }}$ grade course books respectively. It was observed that the speaking strategy activities in the course books by both parties did not show a systematic increase or decrease in terms of grade levels. In the study, it was determined that the most frequently used speaking strategy activities in the MoNE course books was free speech, followed by planned/prepared speech, creative speech, discussion, and talking with empathy, respectively. Therefore, it was seen that talking with empathy in the MoNE publications had been neglected as a strategy. This result is similar to the finding by Sağlam and Yüksel (2019) which reports that listening with empathy activities were not sufficient in terms of quality and quantity in the $7^{\text {th }}$ grade Turkish language MoNE course books. In this study, it was also found that the most frequently used speaking strategy activities in the course books by private publishers were free speech, creative speech, planned/prepared speech, discussion and talking with empathy respectively. The order of the most frequently used speaking strategy activities in both the MoNE and private publisher course books was similar.

Another goal of this study was to determine the distribution of writing strategy activities in the textbooks by the MoNE and private publishers. 618 writing strategy activities were found in all 
grades 1-8 course books published by the MoNE. The number was 555 in the course books by private publishers. The MoNE course books included more types of writing strategy activities. The course books that included writing strategies the most in the MoNE course books were $6^{\text {th }}, 8^{\text {th }}$ and $7^{\text {th }}$ grade textbooks respectively. In the course books by private publishers, the $7^{\text {th }}, 6^{\text {th }}$ and $5^{\text {th }}$ grade course books respectively included writing strategy activities the most. Among the Turkish language course books published by the MoNE and private publishers, the most frequently used writing strategy activities were gap filling, creative writing and controlled writing. The $6^{\text {th }}, 8^{\text {th }}, 5^{\text {th }}$ and $7^{\text {th }}$ grade course books by the MoNE and $5^{\text {th }}, 6^{\text {th }}$ and $7^{\text {th }}$ grade course books by private publishers stood out in terms of the variety of writing strategy activities used. In terms of both types of publishers, it is remarkable that fewer writing strategy activities were included in the $1^{\text {st }}$ and $2^{\text {nd }}$ grade levels. This could be explained through the fact that students in those grades were in the early reading-writing period. 